\title{
The Limits of Cognition and the Limits of Contract
}

\author{
Melvin Aron Eisenberg*
}

Contract law recognizes a number of exceptions to the rule that courts should fully enforce bargains between capable actors. In this article, Professor Eisenberg argues that we can best justify a number of these doctrines by reference to the limits of human cognition. He canvasses recent empirical research on the cognitive limits relevant to contracting and then shows how these discoveries shed light on six areas of contract: liquidated damages, the excuse of express conditions, form contracts, contracts to waive fiduciary obligations, agreements governing thick relationships, and prenuptial agreements. While the limits of cognition do not explain all of contract law, Professor Eisenberg argues, an understanding of the psychological constraints on decisionmaking should play a central role in the development of contract doctrine.

\section{INTRODUCTION}

A basic principle of contract law is that bargains are enforced according to their terms. ${ }^{1}$ This principle-which I will call the bargain principle-finds common expression in such catchphrases as "courts do not inquire into the adequacy of consideration" 2 and "[m]ere inadequacy of consideration will not void a contract." 3 When stated in this way, the bargain principle appears to be a rule about consideration, but it is also a rule about the extent of judicial review and about remedies. As to the former, the principle enjoins the courts to enforce bargains as made, without reviewing their terms. As to the latter, the principle enjoins the courts not only to enforce bargains, but to enforce them to their full extent, so that damages for breach are measured by the value the promised performance would have had to the injured party.

A complex of social propositions supports the bargain principle. Parties are normally the best judges of their own utility, and normally reveal their determi-

* Koret Professor of Law, University of Califomia at Berkeley.

Earlier versions of this article were presented at a workshop at Stanford Law School, at a colloquium at the School of Law of the University of Califomia at Berkeley, and in seminars at the law schools of the University of New South Wales, the University of Adelaide, and Bond University. Valuable suggestions were made in all of these forums.

I especially thank Tom Tyler for his invaluable help on the cognitive material and Matt Forsyth for his invaluable help on prenuptial agreements.

1. By a bargain, I mean an exchange in which each party views his performance as the price of the other party's performance.

2. See Westlake v. Adams, 141 Eng. Rep. 99, 106 (C.P. 1858).

3. Batsakis v. Demotsis, 226 S.W.2d 673, 675 (Tex. Civ. App. 1949); see, e.g., Schweitzer v. Gibson, 151 N.E. 865, 866-67 (Ill. 1926); Restatement (SECOND) OF CoNTRACTS § 79 (1979). 
nations of utility in their promises. Bargain promises are normally made in a deliberative manner for personal gain, and promises so made should normally be kept. Bargains normally create value, enable the parties to plan their future conduct reliably, allocate commodities to their highest-valued uses, and best distribute the factors of production, ${ }^{4}$ and the enforcement of bargain promises promotes these desirable ends. Ultimately, these propositions, and therefore the bargain principle itself, rest on the empirical premise that in making a bargain a contracting party will act with full cognition to rationally maximize his subjective expected utility.

Notwithstanding the bargain principle, contract law sets a variety of limits on the full enforcement of bargain promises. Some of these limits apply to cases in which the promisor has conducted himself in a blameworthy manner. Many of the traditional defenses to contract formation, like duress and misrepresentation, rest on this basis in whole or in part. The principle of unconscionability, ${ }^{5}$ developed and elaborated within the last forty years, is similarly rooted in the idea that a party who has bargained unfairly should not be able fully to enforce the resulting contract. Essentially, the highly general principle of unconscionability has given courts a warrant to develop more specific doctrines for review of contracting behavior ${ }^{6}$ that involves some kind of unfair exploitation of one party by the other, as in the doctrine of unfair surprise. ${ }^{7}$

Some of the doctrines that limit the bargain principle, however, cannot be adequately explained on the basis of unfair exploitation. Rather, these doctrines are best explained on the basis of the limits of cognition.

Consider, for example, the traditional defense of lack of capacity. Lack of capacity exists when a party is not competent to understand the nature and consequences of his acts, is an infant, or is under guardianship. ${ }^{8}$ If a party is not competent to understand the nature and consequences of his acts, he cannot make adequate judgments concerning his utility. If a party is an infant or under guardianship, the law conclusively presumes that he cannot make such judgments. In each case, the party enters into bargain promises with actual or presumed cognitional limits, and therefore the doctrine of capacity does not rest on blameworthy exploitation. Indeed, the incapacity defense is applicable even if the party with capacity neither knew nor had reason to know that the other lacked capacity. 9 Rather, the doctrine of capacity rests on the "assumption that incompetents, properly defined, require protection from their own actions,"10 so that the premise of the bargain principle, that a contracting party will act

4. See Melvin Aron Eisenberg, The Bargain Principle and Its Limits, 95 HARv. L. Rev. 741, 74347 (1982).

5. See U.C.C. \$ 2-302 (1989); Restatement (SeCond) of Contracts \$ 208 (1979).

6. See Eisenberg, supra note 4, at 799 .

7. Under the doctrine of unfair surprise, a contractual provision will not be enforced if one party to a prospective written contract includes a term in the writing that he knows or should know will violate the reasonable expectations that the other party has formed on the basis of such elements as the negotiated terms and the circumstances surrounding the transaction. See notes 168-172 infra and accompanying text.

8. See Restatement (Second) of Contracts §§ 12-15 (1979).

9. Id. $\S 15 \mathrm{cmt}$. $d$.

10. John D. Calamari \& Joseph M. Perillo, Contracts 326 (3d ed. 1987). 
with full cognition to rationally maximize his subjective expected utility, is not fulfilled.

In this article, I will show that limits of cognition also explain many other limits on the bargain principle that apply to classes of contract provisions and classes of contracts that are systematically affected by limits of cognition, so that the premise of the bargain principle is not fulfilled. I will also show how those limits on the bargain principle should be interpreted, modified, and extended. I begin by sketching in Part I the limits of cognition that are most salient to contract law. I then develop in Part II the application of these limits to several areas of contract law: liquidated damages, express conditions, form contracts, contracts to waive fiduciary obligations, contracts to govern the ongoing conduct of thick relationships, and prenuptial agreements.

\section{The Limits of Cognition}

Contracts concern the future, and are therefore always made under conditions of uncertainty. According to the standard economic model of choice, ${ }^{11}$ an actor who must make a choice in the face of uncertainty will rationally select the option that maximizes his subjective expected utility. Rationality requires, among other things, that when consequences are uncertain, their likelihood is evaluated without violating the basic rules of probability theory. ${ }^{12}$ As Tom Ulen observes, the rational choice model requires the strong assumption about cognitive abilities that decisionmakers "know, or can know, all the feasible alternative actions open to them, that they know, or can easily discover, all relevant prices, and that they know their wants and desires." 13 As applied to choices made under conditions of uncertainty, additional strong assumptions about cognitive abilities must be made:

that individual decisionmakers can compute (subjective) probability estimates of uncertain future events; that they perceive accurately the dollar cost or outcome of the uncertain outcomes; that they know their own attitudes toward risk; that they combine this information about probabilities, monetary values of outcomes, and attitudes toward risk to calculate the expected utilities of alternative courses of action and choose that action that maximizes their expected utility. ${ }^{14}$

In fact, however, empirical evidence shows that actors characteristically violate the standard rational-choice or expected-utility model, due to the limits of cognition. In this article, I will focus on three such limits: limits based on bounded rationality and rational ignorance, limits based on disposition, and limits based on defective capability.

11. See Robyn M. Dawes, Rational Choice in an Uncertain World 10-14, 146-63 (1988).

12. Id. at 8 .

13. Thomas S. Ulen, Cognitive Imperfections and the Economic Analysis of Law, 12 HamLIne L. REv. 385, 385-86 (1989).

14. Id. at 386. 


\section{A. Bounded Rationality and Rational Ignorance}

If the costs of searching for and processing (evaluating and deliberating on) information were zero, and human information-processing capabilities were periect, then an actor contemplating a decision would make a comprehensive search for relevant information, would process perfectly all the information he acquired, and would then make the best possible substantive decision-the decision that, as of the time made, was better than all the alternative decisions the actor might have made if he had complete knowledge and perfect processing abilities, and would therefore maximize the actor's subjective expected utility. I will call such a decision an optimal substantive decision.

In reality, of course, searching for and processing information does involve costs, in the form of time, energy, and perhaps money. Most actors either don't want to expend the resources required for comprehensive search and processing or recognize that comprehensive search and processing would not be achievable at any realistic cost. Furthermore, our abilities to process information and solve problems are constrained by limitations of computational ability, ability to calculate consequences, ability to organize and utilize memory, and the like. ${ }^{15}$ Hence, actors will often process imperfectly even the information they do acquire. Such imperfections in human processing ability increase as decisions become more complex and involve more permutations. ${ }^{16}$

Accordingly, human rationality is normally bounded by limited information and limited information processing. ${ }^{17}$ Actors normally do not try to make optimal substantive decisions, but only satisfactory substantive decisions. March and Simon express the distinction between optimal and satisfactory substantive decisionmaking as follows:

An alternative is optimal if: (1) there exists a set of criteria that permits all alternatives to be compared, and (2) the alternative in question is preferred, by these criteria, to all other alternatives. An alternative is satisfactory if: (1) there exists a set of criteria that describes minimally satisfactory alternatives, and (2) the alternative in question meets or exceeds all these criteria.

Most human decisionmaking, whether individual or organizational, is concerned with the discovery and selection of satisfactory alternatives; only in exceptional cases is it concerned with the discovery and selection of optimal alternatives .... An example is the difference between searching a haystack to find the sharpest needle in it and searching the haystack to find a needle sharp enough to sew with. ${ }^{18}$

Although the concept of bounded rationality suggests that actors will adopt selective search and processing procedures, it does not dictate what those procedures will be. Under one model, developed by Stigler, an actor invests in

15. James G. March, Bounded Rationality, Ambiguity, and the Engineering of Choice, 9 BELL J. Econ. 587, 590 (1978); see also Herbert A. Simon, Rational Decisionmaking in Business Organizations, 69 AM. Econ. REv. 493, 502-03 (1979) (sketching the development of the theory of the strategies actors use under bounded rationality).

16. See James G. March \& Herbert A. Simon, Organtzations 171 (1st ed. 1958).

17. See Herbert A. Simon, Administrative Behavior 79-109 (3d ed. 1976).

18. MARCH \& Simon, supra note 16 , at $140-41$. 
search until the cost of further search equals the marginal returns from further search. ${ }^{19}$ At that point, the actor terminates search. This model of decisionmaking is itself an optimizing model, in which an actor optimizes his search but then makes a decision, based on his bounded search, that may or may not be substantively optimal. ${ }^{20}$ This model can be applied to the amount of information processing that an actor engages in, as well as the duration of his search. I will call a model in which the amount of search and information processing are optimal, but the substantive decision may not be, the model of optimal decisionmaking procedure. A major implication of this model is that actors will make decisions in a state of rational ignorance of alternatives and consequences that could have been discovered and considered if search and processing had continued.

Simon has advanced an alternative model of decisionmaking. According to Simon's model, prior to search an actor sets an initial target level of aspiration or satisfaction. (The actor may fine tune this level of aspiration during search.) When the actor discovers an alternative that meets his predetermined level of aspiration, he terminates his search and processing and chooses that alternative. Simon calls this model "satisficing." 21 "Whereas economic man maximizes - selects the best alternative from among all those available to him, his cousin, administrative man, satisfices-looks for a course of action that is satisfactory or 'good enough.' "22

Many other procedural strategies are possible. For example, actors frequently use rule-of-thumb heuristics (decision rules) to make particular kinds of recurring decisions. Thus, Kunreuther studied households located in floodprone or earthquake-prone areas to determine how these households decided whether to purchase disaster insurance, and found that rather than attempting to gather and use available information to estimate the net benefits of purchasing such insurance, households are more likely to follow a rule of thumb, such as "do as my neighbor does." 23

For purposes of this article, I will assume that the model of optimal decisionmaking procedure governs the amount of search and processing in which actors engage. ${ }^{24}$ This model does not exhaust the concept of bounded rationality. The model describes only the amount, not the quality, of search and

19. George J. Stigler, The Economics of Information, 69 J. PoL. Scr. 213 (1961).

20. This model of decisionmaking is based on classical expected-utility maximization, as applied to search decisions rather than to substantive decisions.

21. Simon, supra note 15, at 502-03; Herbert A. Simon, Theories of Bounded Rationality, in Decision and Organization 161 (C.B. McGuire \& Roy Radner eds., 2d ed. 1986).

22. Simon, supra note 17 , at $\mathrm{xxix}$.

23. Howard Kunreuther, Limited Knowledge and Insurance Protection, 24 PuB. PoL'y 227, 255 (1976); see also Lee S. Friedman, Bounded Rationality Versus Standard Utility-Maximization: A Test of Energy "Price" Responsiveness (Jan. 1993) (unpublished manuscript, on file with the Stanford Law Review) (finding that households usually base energy consumption decisions on the household's total energy bill, rather than on detailed information in the bill that shows how energy rates vary at different levels of consumption).

24. Some commentators use the term "satisfice" as an equivalent to this model. See, e.g., David M. Grether, Alan Schwartz \& Louis L. Wilde, The Irrelevance of Information Overload: An Analysis of Search and Disclosure, 59 S. CAL. L. REv. 277,279 (1986) ("To optimize is to choose the best from the full set of market choices; to satisfice is to do as well as one can, given the circumstances."). 
processing. In contrast, the concept of bounded rationality also includes the fact that actors will not process information perfectly even if they wish to do so, because human ability to calculate consequences, understand implications, and make comparative judgments on complex alternatives is limited.

That actors limit search and processing does not necessarily mean that they fail to rationally maximize their total utility in making decisions. An actor's total utility from a decision depends not only on the substantive merits of the decision, but also on the costs of the decisionmaking procedure. Limits on search and processing costs may maximize an actor's overall utility, because the utility gain from substituting the lower cost of limited search and processing may offset the utility shortfall from substituting a satisfactory substantive decision for an optimal substantive decision. For purposes of this article, I will assume that the calculating abilities of actors are limited in ways they may or may not be aware of, but that in determining the appropriate amount of search and processing actors follow the model of optimal decisionmaking procedure, so that their ignorance of undiscovered alternatives is rational, although their calculations concerning the alternatives they do consider may not be.

\section{B. Disposition}

Although bounded rationality does not necessarily lead actors to make irrational decisions, two bodies of empirical evidence show that under certain circumstances, actors are often systematically irrational; that is, they often fail to make rational decisions even within the bounds of the information they have acquired.

One body of evidence concerns disposition. This evidence shows that as a systematic matter, people are unrealistically optimistic. ${ }^{25}$ Nearly ninety percent of drivers believe they drive better than average. ${ }^{26}$ Ninety-seven percent of consumers believe that they are either average or above average in their ability to avoid accidents involving bicycles and power mowers. ${ }^{27}$ In a study by Viscusi and Magat, in which consumers were informed of the true average risks presented by bleach and drain cleaner, only 3 percent of consumers considered their homes to present an above-average risk of hand burn and child poisoning from the use of drain cleaner, or gas poisoning or injury to children from the use of bleach. Roughly half considered their homes to be about average in risk, and the other half believed their household had lower-than-average risk. Consumers were particularly optimistic about child poisoning from drain cleaner, which was by far the most severe risk. Sixty-five percent considered

25. Neil D. Weinstein, Unrealistic Optimism About Future Life Events, 39 J. Personaltry \& Soc. Psychol. 806 (1980). Related to undue optimism is the tendency of actors systematically to underestimate risks. See text accompanying notes 69-73 infra.

26. Ola Svenson, Are We All Less Risky and More Skillful Than Our Fellow Drivers Are?, 47 Acta Psychologica 143 (1981), cited in Colin F. Camerer \& Howard Kunreuther, Decision Processes for Low Probability Events: Policy Implications, 8 J. PoL'Y Anal. \& MGMr. 565, 569 (1989).

27. W. Kip Viscusi \& Wesley A. Magat, Learning about Risk: Consumer and Worker RESPONSES tO HAZARD INFORMATION 95 (1987). 
their family's risk from this hazard to be below average, while only 3 percent considered their family's risk from this hazard to be above average. ${ }^{28}$

Similarly, when people rate their chances for personal and professional success, most unrealistically believe that their chances are better than average. ${ }^{29}$ In one study, Weinstein asked college students whether they believed their chances of experiencing certain favorable or unfavorable life events differed from the average chances of all other students of the same sex at the same college. Six times the number of students optimistically thought they were more likely than their average classmate to own their own home than pessimistically thought they were less likely. Seven times as many students thought they were less likely than their average classmate to have a drinking problem than thought they were more likely. Six times as many thought they were more likely than their average classmate to like their postgraduate job than thought they were less likely. More than nine times as many students thought they were less likely than their average classmate to divorce a few years after marriage than thought they were more likely. Answers about all other life events skewed in the same optimistic direction, and a number of the answers reflected similar ratios between optimistic and pessimistic responses. ${ }^{30}$ Similarly, actors tend to be overconfident of their ability to resolve uncertain factual issues and are particularly likely to be overconfident where the judgments are difficult. ${ }^{31}$

The dispositional characteristic of undue optimism is strikingly illustrated in a recent study by Baker and Emery, appropriately titled When Every Relationship Is Above Average. ${ }^{32}$ Baker and Emery surveyed people who were about to get married concerning their own perceived divorce-related prospects as compared to the prospects of the general population. The disparities between perceptions as to the general population and expectations as to self were enormous and were almost invariably in the cirection of optimism. For example, the respondents correctly estimated that 50 percent of American couples will eventually divorce. In contrast, the respondents estimated that their own chance of divorce was zero. ${ }^{33}$ Similarly, the median estimate of the female respondents was that courts award alimony to 40 percent of women who divorce. In contrast, 81 percent of the female respondents expected that a court would award them alimony if they requested it. ${ }^{34}$ The respondents' median estimate of how often spouses pay alimony when ordered by a court to do so was that 40 percent paid. In contrast, 100 percent of the respondents predicted

28. Id. at 94-95.

29. Weinstein, supra note 25 , at 809-14.

30. Id; see also Camerer \& Kunreuther, supra note 26, at 569 (discussing the empirical evidence for systematic optimism); Richard G. Noll \& James E. Krier, Some Implications of Cognitive Psychology for Risk Regulation, 19 J. LEGAL STUD. 747, 757-58 (1990) (providing a mathematical model of the "optimism effect" on decisionmaking).

31. Ward Edwards \& Detlof von Winterfeldt, Cognitive Illusions and Their Implications for the Law, 59 S. CAL. L. REv. 225, 239 (1986).

32. Lynn A. Baker \& Robert E. Emery, When Every Relationship Is Above Average: Perceptions and Expectations of Divorce at the Time of Marriage, 17 LAw \& Hum. BeHAv. 439 (1993).

33. Id. at 443.

34. Id. 
that their own spouse would pay all court-ordered alimony. ${ }^{35}$ The same optimism permeated views on child custody. The median estimate of the female respondents was that children from divorced families live mostly with their mothers 80 percent of the time. In contrast, more than 95 percent of the women expected that they would get primary custody in a divorce. The median estimate of the male respondents was that children from divorced families live mostly with their fathers 20 percent of the time. In contrast, more than 40 percent of the men expected that they would get primary custody in a divorce. ${ }^{36}$

\section{Defective Capability}

Just as defects in disposition systematically tilt an actor's judgment toward optimism, so defects in capability systematically distort the way an actor searches for, processes, and weighs information and scenarios. As Tversky and Kahneman point out, expected-utility theory "emerged from a logical analysis of games of chance rather than from a psychological analysis of risk and value. The theory was conceived as a normative model of an idealized decision maker, not as a description of the behavior of real people." 37 In fact, however, within the last thirty years cognitive psychology has established that real people use certain decisionmaking rules (heuristics) that yield systematic errors, and that other aspects of actors' cognitive capabilities are also systematically defective. "[T] he deviations of actual behavior from the normative model are too widespread to be ignored, too systematic to be dismissed as random error, and too fundamental to be accommodated by relaxing the normative system." 38

For example, a basic assumption of expected-utility theory, sometimes called invariance, is that a decisionmaker's preference between two options should not depend on how a choice is characterized and presented, or "framed." Invariance requires that actors make choices based on real consequences, ${ }^{39}$ so that two characterizations or presentations of the same option should lead to the

35. Id. An arguable exception to this consistent optimism was that although the median male respondent estimated that courts award alimony to only $50 \%$ of divorcing women, $83 \%$ of the male respondents expected that a court would award alimony to their wives if they requested it. Id. In their article, Baker and Emery characterize this response as overly optimistic, see id., but Baker now believes that the response might better be characterized as an overestimation of the relevant likelihood. Letter from Lynn Baker to Melvin Aron Eisenberg (Sept. 30, 1993) (on file with the Stanford Law Review).

36. Baker \& Emery, supra note 32, at 443.

37. Amos Tversky \& Daniel Kahneman, Rational Choice and the Framing of Decisions, $59 \mathrm{~J}$. Bus. S251, S251 (Supp. 1986).

38. Id. at S252; see also Camerer \& Kunreuther, supra note 26, at 568 ("The [expected-utility] model is simple and easy to use in theoretical applications. It has been shown to be an inadequate description of individual choices in many ways, however. Many descriptive violations arise because people use heuristic rules to estimate probabilities-rules that yield systematic enrors.") (citation omitted). As Ulen has observed:

There is a mounting body of evidence that ... many, perhaps most, individuals routinely make errors in the routine processing of information. The [implication] of this finding is that individuals may make many more errors in their attempts to maximize their utility or profit than the rational choice model assumes; that these errors are not due to the standard sorts of market imperfections but rather to a novel set of individual imperfections I call 'cognitive imperfections'; [and] that these errors are systematic, not randomly distributed with mean zero . ... Ulen, supra note 13 , at $387-88$.

39. DAwEs, supra note 11 , at 34-35. 
same choice. ${ }^{40}$ It has been repeatedly shown, however, that in reality choice often does depend on how outcomes are framed. ${ }^{41}$

For example, whether substantively identical options are framed as gains or losses has a decisive effect on actors' choices. ${ }^{42}$ This kind of framing effect builds on the fact that most people are risk-averse when contemplating gains, but risk-preferring when contemplating losses. ${ }^{43}$ Thus, given a choice between a sure gain of $\$ 800$ and an 85 percent chance to win $\$ 1000$, most people prefer the sure gain over the chance even though the chance has a higher expected value. In contrast, given a choice between a sure loss of $\$ 800$ and an 85 percent chance to lose $\$ 1000$, most people prefer the chance over the sure loss even though the chance has a lower mathematical value. ${ }^{44}$

These contrasting preferences are not in themselves irrational, but they can be manipulated by framing to produce irrational choices. In a famous experiment, Tversky and Kahneman presented subjects with two problems concerning a choice of alternative programs to combat a disease that would otherwise kill 600 people. ${ }^{45}$ In problem I, the subjects were told that program A would save 200 lives, while program B carried a one-third probability of saving 600 lives. In problem II, the subjects were told that program A would cost 400 lives, while program B carried a two-thirds probability of losing 600 lives. A moment's reflection shows that each program $A$ is identical, as is each program B. Nevertheless, because problem I was framed in terms of gains (lives saved) and therefore invoked risk-aversion, while problem II was framed in terms of losses (lives lost) and therefore invoked risk-preference, 72 percent of the respondents chose program $A$ in problem I, while 78 percent chose program $B$ in problem II. ${ }^{46}$

Another example of framing is the characterization of an option as insurance or as gambling. For example, when offered a hypothetical choice between a sure loss of $\$ 50$ and a 25 percent chance to lose $\$ 200$, most people chose the former when the choice was posed as a question of insurance, and the latter when it was presented as a question of gambling. ${ }^{47}$

40. Daniel Kahneman \& Amos Tversky, Choices, Values, and Frames, 39 Am. Psychol. 341, 343 (1984); Tversky \& Kahneman, supra note 37, at \$253.

41. See, e.g., Camerer \& Kunreuther, supra note 26, at 572-74; Kahneman \& Tversky, supra note 40, at 343-44; Noll \& Krier, supra note 30, at 753-54.

42. See, e.g., Kahneman \& Tversky, supra note 40 , at 349.

43. Amos Tversky \& Daniel Kahneman, The Framing of Decisions and the Psychology of Choice, 211 SCIENCE 453, 453 (1981). Risk preference in the case of losses may not apply at the extreme ends of the spectrum, that is, where the probability of winning or losing is small, on the one hand, or the loss would be catastrophic, on the other. See Tversky \& Kahneman, supra note 37, at S255, S258.

44. Kahneman \& Tversky, supra note 40 , at 342; see also Noll \& Krier, supra note 30, at 752 (presenting algebraic formulas for the proposition that people are loss-averse as to gains but risk-preferring as to losses).

45. See Tversky \& Kahneman, supra note 43 , at 453-55.

46. Id. at 453 .

47. Baruch Fischoff, Cognitive Liabilities and Product Liability, 1 J. Prod. LiaB. 207, 213 (1977); Kahneman \& Tversky, supra note 40, at 349; Paul Slovic, Baruch Fischoff \& Sarah Lichtenstein, Response Mode, Framing, and Information-Processing Effects in Risk Assessment, in QUESTION FrAMING and Response Consistency 21, 22-28 (Robin M. Hogarth ed., 1982). 
The framing effect is so strong that many people will stand by their inconsistent choices even when they know of the inconsistencies. On several occasions, Tversky and Kahneman presented the same respondents with the two versions of the disease problem. ${ }^{48}$ When Tversky and Kahneman discussed with the respondents the inconsistent preferences evoked by the two versions, many chose to remain risk-averse in the lives-saved version and risk-preferring in the lives-lost version, even though they wanted their answers to be consistent. ${ }^{49}$ Similarly, Lewis found that even after researchers showed a group of undergraduate students that they had made inconsistent choices on the basis of framing effects, half the students refused to change their responses to make them consistent. ${ }^{\text {so }}$ As Kahneman and Tversky comment:

The failure of invariance is both pervasive and robust. It is as common among sophisticated respondents as among naive ones, and it is not eliminated even when the same respondents answer both questions within a few minutes.... In their stubborn appeal, framing effects resemble perceptual illusions more than computational errors. ${ }^{51}$

The framing effect is a particularly dramatic illustration of how actors use systematically flawed heuristics. The effect may be relevant to contract law because, for example, it may help explain how door-to-door sellers can manipulate the preferences of buyers, and may therefore justify rules such as the cooling-off period in door-to-door sales, which gives consumers several days to reconsider and cancel orders. ${ }^{52}$ In the balance of this article, however, I will emphasize the effects on contract law of four other systematic defects in capability: defects associated with the heuristics known as availability and representativeness, defective telescopic faculties, and defective risk-assessment faculties.

\section{Availability.}

Because human information-processing ability is limited, actors who have acquired information that is relevant to a decision, either through a present search or past learning, must employ heuristics to process the information efficiently. One of these heuristics is known as availability. ${ }^{53}$ When an actor must make a decision that requires a judgment about the probability of an event, he commonly judges that probability on the basis of comparable data and scenarios that are readily available to his memory or imagination. This heuristic 453.

48. See Kahneman \& Tversky, supra note 40 , at 343 ; Tversky \& Kahneman, supra note 43 , at

49. Kahneman \& Tversky, supra note 40 , at 343.

50. See DAwes, supra note 11, at 36-37 (discussing the research of Scott B. Lewis).

51. Kahneman \& Tversky, supra note 40 , at 343.

52. See, e.g., 16 C.F.R. § 429.1 (1994).

53. See Dawes, supra note 11, at 92-94; Susan T. Fiske \& Shelley E. Taylor, Social CogmTION 270-71 (1984); Kunreuther, supra note 23, at 243; Amos Tversky \& Daniel Kahneman, Availability: A Heuristic for Judging Frequency and Probability, in JUdGMENT UNDER UNCERTANTTY: Heuristics and Biases 164, 166, 174-75 (Daniel Kahneman, Paul Slovic \& Amos Tversky eds., 1982) [hereinafter Tversky \& Kahneman, Availability]; Amos Tversky \& Daniel Kahneman, Judgment Under Uncertainty: Heuristics and Biases in JUdGMENT UNDER UNCERTAINTY: HeURISTICS AND BIASES, supra, at 3,11 [hereinafter Tversky \& Kahneman, Judgment]. 
leads to systematic biases, because factors other than objective frequency and probability affect the salience of data and scenarios, and therefore affect the ease with which an actor imagines a scenario or retrieves data from memory. ${ }^{54}$

For example, in one experiment researchers recited lists of well-known personalities to groups of subjects. All the lists contained names of both men and women, but in some lists the men were more famous than the women, while in others the women were more famous than the men. When asked to determine whether men or women were more numerous in a list, the subjects erroneously concluded that the class that had more famous personalities was the more numerous. ${ }^{55}$ Similarly, recent occurrences are usually easier to retrieve from memory than earlier occurrences. Tversky and Kahneman point out, "It is a common experience that the subjective probability of traffic accidents rises temporarily when one sees a car overturned by the side of the road."56

Independent significance (like fame in the list experiment) and spatial or temporal proximity (as in the traffic-accident example) are two elements that may make data salient and therefore more easily retrievable. In addition, data and scenarios that are instantiated, vivid, and concrete will normally be more salient than data and scenarios that are general, pallid, and abstract, such as statistical findings and generalized probabilities. ${ }^{57}$ For example, Lichtenstein, Slovic, Fischoff, Layman, and Combs asked a large number of respondents to estimate the frequency of forty-one causes of death in the United States. ${ }^{58}$ The respondents overestimated the frequency of memorable and dramatic killers, like homicide, accidents, and natural disasters, and underestimated the frequency of quiet killers, like asthma, emphysema, and diabetes. ${ }^{59}$ Similarly, an

54. DAWES, supra note 11, at 92-94; $c f$. Daniel Kahneman \& Dale T. Miller, Norm Theory: Comparing Reality to Its Alternatives, 93 PsYcHOL. REv. 136, 141-42 (1986) (expanding on the availability heuristic by analyzing the relationship between a stimulus and those past experiences or ad hoc constructions that constitute the "norm" against which the stimulus is compared).

55. Tversky \& Kahneman, Judgment, supra note 53, at 1127.

56. Id.

57. See Richard NisbetT \& Lee Ross, Human InFerence: STRATEgIES AND SHORTCOMINGS OF SOCIAL JUDGMENT 43-62 (1980) (concluding that it may be presumed that inferences and behavior are much more influenced by vivid, concrete information than by pallid, abstract information of greater evidentiary value); $c f$. Tversky \& Kahneman, Availability, supra note 53, at 176 (proposing that actors may give undue weight to salient memories over more relevant facts when making judgments about whether a particular event will happen). Fiske and Taylor distinguish "salience," which they define as "a property of stimuli in context," from "vividness," which they define as "an inherent property of stimuli." FISKE \& TAYLOR, supra note 53, at 190 . They then conclude that there is experimental evidence for the effect of salience, but not for the effect of vividness, with the exception of case studies. Id. at 190-92. However, this definition seems artificial: Most people would consider data to be vivid whether that property is an inherent property of the data or is a property of the data in context. Having drawn an artificial distinction, Fiske and Taylor arrive at a proposition that is almost tautologically true, because few if any data are "inherently" vivid without regard to context.

58. Sarah Lichtenstein, Paul Slovic, Baruch Fischoff, Mark Layman \& Barbara Combs, Judged Frequency of Lethal Events, 4 J. EXPERIMENTAL Psychol.: Hum. LEARNING \& MEMORY 551 (1978).

59. Id. at 555-57 \& tbl. 2. Similarly, Borgida and Nisbett gave information about psychology courses to psychology majors trying to choose their classes. Some students were given information orally by two or three other students who had taken the course; others received statistical summaries of the reports of dozens of students who had taken the same course. The oral communications had a much greater effect than the statistical summaries. Eugene Borgida \& Richard E. Nisbett, The Differential Impact of Abstract vs. Concrete Information on Decisions, 17 J. AppLIEd Soc. PsYchol. 258 (1977); see also NiseEtr \& Ross, supra note 57, at 52, 57-58 (describing other experiments). 
actor may assess the risk of heart attack among middle-aged people by recalling such occurrences among his middle-aged acquaintances. Or an actor may evaluate the likelihood that a given business venture will fail by canvassing those potential business difficulties that come readily to mind.60 In general, "[v]ibrant examples simply outweigh more reliable, but abstract baserate information."61

\section{Representativeness.}

The availability heuristic concerns the manner in which actors bring acquired data to mind and imagine future scenarios. Another heuristic, representativeness, concerns the manner of making judgments concerning the adequacy of search. As the concept of bounded rationality implies, actors seldom collect all relevant data before making decisions. Rather, they usually make decisions on the basis of some subset of the data that they judge to be representative. ${ }^{62}$ In making that judgment, however, actors systematically and erroneously view unduly small samples as representative.63 In particular, actors systematically and erroneously take the small sample of present events as representative, and therefore predictive, of future events. ${ }^{64}$ In this way, as Arrow has observed, "[t]he individual judges the likelihood of a future event by the similarity of the present evidence to it," while ignoring other evidence, such as prior occurrences and the quality of the sample. ${ }^{65}$

\section{Faulty telescopic faculties.}

Another type of defect in cognition concerns the ability of actors to make rational comparisons between present and future states: Actors systematically give too little weight to future benefits and costs as compared to present benefits and costs. ${ }^{66}$ Thus, Feldstein concludes that "some or all individuals have, in Pigou's ... words, a 'faulty telescopic faculty' that causes them to give too little weight to the utility of future consumption."67 For example, a major rationale for mandatory and voluntary but tax-favored pension programs is that most people lack the foresight to adequately save for retirement because of faulty telescopic faculties. ${ }^{68}$

60. Tversky \& Kahneman, Judgment, supra note 53, at 1127.

61. FISKE \& TAYLOR, supra note 53, at 252.

62. See, e.g., id. at 268-69; Tversky \& Kahneman, Judgment, supra note 53, at 1124.

63. See Amos Tversky \& Daniel Kahneman, Belief in the Law of Small Numbers, in Judgment UNDER UNCERTAINTY: HEURISTICS AND BIASES, supra note 53, at 23, 24-25 (concluding that scientists and laypersons alike tend to view small random samples as highly representative of populations). (1982).

64. See Kenneth J. Arrow, Risk Perception in Psychology and Economics, 20 Econ. INQuIRY 1, 5

65. Id.; see also FISKE \& TAYLOR, supra note 53, at 269-700 (discussing the representativeness heuristic). (1985).

66. Martin Feldstein, The Optimal Level of Social Security Benefits, 100 Q.J. EcoN. 303, 307

67. Id. (quoting, although slightly incorrectly, A.C. Pigou, The Economics of Welfare (1920). The actual quote is: "[O]ur telescopic faculty is defective, and ... we, therefore, see future pleasures, as it were, on a diminished scale." A.C. Pigou, The Economics of Welfare 25 (4th ed. 1960)).

68. Id. at 303. 


\section{Faulty risk-estimation faculties.}

Related to actors' faulty telescopic faculties is the systematic underestimation of risks. ${ }^{69}$ Based on the work of cognitive psychologists, especially Tversky and Kahneman, Arrow observes that "[i]t is a plausible hypothesis that individuals are unable to recognize that there will be many surprises in the future; in short, as much other evidence tends to confirm, there is a tendency to underestimate uncertainties."70

In fact, empirical evidence shows that people often not only underestimate but ignore low-probability risks. In interviews with 2055 homeowners living in flood-prone areas throughout the United States and 1006 homeowners in earthquake-prone areas in California, Kunreuther and Slovic found that many residents had little idea of the real probability of a future disaster or of their own potential damage from such an occurrence. ${ }^{71}$ Of the uninsured subjects in the flood-prone-area survey, 29 percent expected that they would suffer no damage in a severe flood, and 26 percent expected that their damage would be $\$ 10,000$ or less. Of the uninsured respondents in the earthquake-prone-area survey, 12 percent expected that they would suffer no damage in a severe earthquake, and 19 percent expected that they would suffer damages of only $\$ 10,000$ or less. ${ }^{72}$ Even many interviewees who had informed notions of expected losses and premium costs declined to buy insurance in the manner predicted by the expectedutility model. ${ }^{73}$

Similarly, laboratory results consistently demonstrate that even when offered subsidized premiums, people prefer to insure only against highprobability, low-loss hazards and tend to reject insurance against lowprobability, high-loss hazards. ${ }^{74}$ When asked about their insurance decisions, subjects in both the survey and laboratory studies indicated a disinclination to worry about low-probability hazards. ${ }^{75}$

On the other hand, there is empirical evidence that people sometimes overestimate low-probability risks. ${ }^{76}$ Prospect theory, a mathematical treatment of the limits of cognition, predicts that actors either will entirely ignore or overestimate low probabilities, ${ }^{77}$ so that their estimation of low-probability risks will be very unstable. ${ }^{78}$ Although prospect theory does not predict under what con-

69. See Thomas H. Jackson, The Logic and Limits of BankRuptcy Law 237-40 (1986).

70. Arrow, supra note 64 , at 5 .

71. Kunreuther, supra note 23, at 232-33; Howard Kunreuther \& Paul Slovic, Economics, Psychology, and Protective Behavior, AM. Econ. REv., May 1978 (papers \& proceedings), at 64, 66-67.

72. Kunreuther, supra note 23, at 234 tbl. 3.

73. Kunreuther \& Slovic, supra note 71, at 66-67.

74. Id. at 67.

75. Id.; see also Camerer \& Kunreuther, supra note 26, at 565-92 (reviewing empirical evidence that people ignore or underestimate low-probability, high-consequence risks, and analyzing the reasons); Albert R. Karr, False Sense of Security and Cost Concerns Keep Many on Flood Plains From Buying Insurance, WALL ST. J., Aug. 31, 1993, at A12 (citing statistics and field interviews for the proposition that most people in flood-prone areas do not purchase flood insurance due, in part, to an it-can't-happenhere attitude).

76. VISCUSI \& MAGAT, supra note 27, at 83-97.

77. Camerer \& Kunreuther, supra note 26, at 572.

78. Kahneman \& Tversky, supra note 40 , at 345 . 
ditions low probabilities will be overweighed and under what conditions they will be ignored, it seems likely that actors will ignore low-probability risks unless they are highly salient. ${ }^{79}$ Viscusi and Magat hypothesize that the empirical results in this area may depend on whether the data are produced by an experiment or reflect actual decisions that actors have made, like failing to insure. ${ }^{80}$ According to this hypothesis, when actors are forced to confront a low-probability risk, as they are in experiments, they tend to overestimate the risk; when they are not forced to confront the risk, as is often the case in realworld decisions, they tend to ignore the risk. Thus, as Latin notes, overestimation "may be applicable when people must consider low-probability risks, but bounded rationality and non-availability considerations may induce people to disregard many unlikely risks in everyday life."81 Still another possibility, which is consistent with most or all of the empirical evidence, is that actors tend to overestimate low-probability risks of personal physical injury of which they are made aware, but tend to ignore or underestimate other low-probability risks. On balance, it is clear that risk estimation is highly unstable, and the evidence strongly suggests that people systematically underestimate most risks, including low-probability risks of economic losses.

The defects in cognition discussed above are closely related and interactive. For example, people may underweigh future costs in part because the future involves a great number of risks, and actors underestimate risks, and in part because the present is vivid, concrete, and instantiated, while the future is pal-

79. See Camerer \& Kunreuther, supra note 26, at 570; Howard Latin, "Good" Warmings, Bad Products, and Cognitive Limitations, 41 UCLA L. Rev. 1193, 1245-47 (1994).

80. VISCusi \& MAGAT, supra note 27, at 91 . The authors note:

If people have difficulty internalizing low probabilities but are forced by a survey to consider them in making decisions, they may respond by mentally augmenting the probability to a level that is familiar to them. In contrast, if decisionmakers are allowed to ignore low-probability events, as in making actual flood insurance decisions, they may do so in order to simplify the processing costs of making those decisions.

Id.; see also Latin, supra note 79, at 1246 ("One explanation for the disparity between experimental evidence that low-probability risks are overweighed and observations that people often ignore these risks is that experimental methodology forces high salience for the risks under study while 'real life' experiences seldom make low-probability risks available.").

81. Latin, supra note 79 , at 1246 . Zeckhauser and Viscusi have claimed that "people generally overestimate the likelihood of low-probability events ... ." Richard J. Zeckhauser \& W. Kip Viscusi, Risk Within Reason, 248 ScIENCE 559, 560 (1990). However, that claim is contradicted both by theory, which predicts that people will either overestimate or ignore such risks, and empirical evidence, such as that gathered by Kunreuther and Slovic concerning flood and earthquake insurance, which shows that people often underestimate or entirely ignore low-probability risks. See notes 71-75 supra and accompanying text. Zeckhauser and Viscusi rely partly on the data of Lichtenstein et al. concerning people's estimates of the frequency of causes of death, see text accompanying notes 58-59 supra, but those estimates are not based on whether different causes of death are low-risk or high-risk (most are lowrisk), but on the salience and availability of the various causes of death. In fact, Zeckhauser and Viscusi's claim contradicts even Viscusi's earlier work. See VIscusi \& MAGAT, supra note 27, at 90-91.

Furthermore, in some of the cases in which people may overestimate a low-probability risk, such as the risk of an accident in a nearby nuclear generator, it may be that what seems to be overestimation of risk is in fact based on a complex of other factors, such as the magnitude of the worst-case scenario and a special distaste for risks that are involuntarily imposed. See generally K.S. SHRAder-FrechetTE, Risk and Rationality: PhILosophical Foundations for Populist Reforms (1991); Jeremy Waldron, K.S. Schrader-Frechette, Risk and Rationality: Philosophical Foundations for Populist Reforms, 20 ECOLOGY L.Q. 347, 347-48 (1993) (book review). 
lid, abstract, and general. Conversely, people may underestimate risks in part because risks are often pallid, abstract, and general, and in part because risks relate to the future, and actors give too little weight to future costs.

These defects in cognition are also closely related to and interact with the dispositional problem of unrealistic optimism: If actors are unrealistically optimistic, they will systematically underestimate risks. If actors systematically underestimate risks, they will be unrealistically optimistic.

Finally, these defects in cognition are closely tied to bounded rationality: Availability and representativeness, for instance, would not even come into play if search and processing were unbounded. Only where actors rely on selective, incomplete information does undue emphasis on available and unrepresentative data pose a problem.

\section{ApPLications}

In Part I, I showed that in making decisions under uncertainty actors for the most part deliberately make a less than perfect search for information and engage in less than perfect processing of the information they do acquire; are systematically disposed toward undue optimism; and labor under systematic defects in capability. In Part II, I will show that these limits of cognition bear with special force on certain classes of contract provisions (such as liquidated damages provisions and express conditions) and certain kinds of contracts (such as form contracts, contracts to waive fiduciary duties, contracts to govern thick relationships, and prenuptial agreements). Generally speaking, the courts have recognized that these types of contracts and contract provisions require special treatment, but typically this special treatment is not explicitly justified on the basis of the limits of cognition. As a result, the relevant doctrines often seem to lack a satisfactory or even a coherent explanation. The limits of cognition both provide that explanation and help to show how the doctrines should be fashioned.

\section{A. Liquidated Damages}

It is a basic principle of contract law that contractual provisions that liquidate damages for breach are not enforceable in the same way as most other kinds of bargain terms, but instead are reviewed with special scrutiny. The formulations of this principle vary, ${ }^{82}$ and, as I will show, many of the formulations are profoundly ambiguous, ${ }^{83}$ but stated at the most general level the principle is as follows: Liquidated damages provisions are enforceable if but only if two conditions are satisfied: (I) Actual damages are difficult to estimate; and (II) the amount fixed in the provision is a reasonable estimate of the actual loss. I will call these two conditions requirements I and II. Courts label liquidated

82. For various formulations, see, for example, Restatement of Contracts § 339 (1932); REstatement (Second) of Contracts $\$ 356$ \& cmt. $b$ (1979); 3 Dan B. Dobes, Law of Remedies: Damages-Eoutry-Restitution \$12.9 (Practitioner Treatise Series, 2d ed. 1993).

83. See text accompanying notes $98-118$ infra. 
damages provisions that do not satisfy these two requirements "penalties" and decline to enforce them. ${ }^{84}$

Many have questioned the principle that courts should give special scrutiny to liquidated damage provisions. Although the arguments vary, Judge Posner's critique in Lake River Corp. v. Carborundum $\mathrm{Co}^{85}$ is fairly typical: "[T] parties (always assuming they are fully competent) will, in deciding whether to include a penalty clause in their contract, weigh the gains against the costs ... and will include the clause only if the benefits exceed those costs . . ."86 Goetz and Scott make a simpler but related critique: "There is no reason to presume that liquidated damages provisions are more susceptible to duress or other bargaining aberrations than other contractual allocations of risk."87

Most critiques, like those of Posner and Goetz and Scott, have an implicit or explicit three-part structure. They begin by assuming that the major justification for the principle that liquidated damages provisions should be given special scrutiny is that such provisions lend themselves to blameworthy exploitation of one party by the other, and consequent one-sidedness, in a way that other types of contract provisions do not; they then argue that this justification won't hold; and they conclude that the special principle is therefore unjustified. So, for example, Goetz and Scott argue that the principle of special scrutiny of liquidated damages provisions arose in a historical context in which protections against fraud and duress were not available. Given the modern development of unconscionability as a unifying unfairness principle, they suggest, the law should simply collapse the treatment of liquidated damages into that principle. ${ }^{88}$

84. See Higgs v. United States, 546 F.2d 373, 377 (Ct. Cl. 1976); Southwest Eng'g Co. v. United States, 341 F.2d 998, 1001 (8th Cir. 1965), cert. denied, 382 U.S. 819 (1965); Security Safety Corp. v. Kuznicki, 350 Mass. 157, 158, 213 N.E.2d 866, 867 (1966); Massey v. Love, 478 P.2d 948, 950 (Okla. 1971); Chaffin v. Ramsey, 276 Or. 429, 431-32, 555 P.2d 459, 461 (1976); Samuel A. Rea, Jr., Efficiency Implications of Penalties and Liquidated Damages, 13 J. LEGAL STUD. 147, 150 (1984) ("Mn many states, courts express the penalty rule in words that are identical to the First Restatement of Contracts, § 339(1): the damage agreement is not enforceable unless it was a reasonable forecast of the harm and the harm is difficult to estimate.").

85. 769 F.2d 1284 (7th Cir. 1985) (Posner, J.).

86. Id. at 1289.

87. Charles J. Goetz \& Robert E. Scott, Liquidated Damages, Penalties and the Just Compensation Principle: Some Notes on an Enforcement Model and a Theory of Efficient Breach, 77 CoLUM. L. Rev. 554, 592 (1977); see also 3 DoBBs, supra note 82, § 12.9(1), at 246:

The penalty rules resulted from a particular history of doubtful relevance in present-day life, and specifically from oppressive and unfair contracts enforced in a medieval, non-market economy. The penalty rules developed primarily to deal, albeit in a crude way, with unconscionable contracts. There are now many other methods for identifying and controlling unconscionable contracts and the penalty rules may not be needed for this purpose except in the most unusual cases.

Id. (footnote omitted). For other standard arguments against the special principle governing liquidated damages provisions, see $i d$. $\$ 12.9(3)-(4)$.

88. Goetz \& Scott, supra note 87, at 593-94; see also Alan Schwartz, The Myth that Promisees Prefer Supracompensatory Remedies: An Analysis of Contracting for Damage Measures, 100 YALE L.J. 369,370 (1990) (arguing that because parties do not in fact want penalty liquidated damage clauses which provide for supracompensatory damages, judicial prohibition of penalty clauses is unnecessary and potentially harmful). 
The assumption that special scrutiny of liquidated damages provisions is justified primarily by a special potential for blameworthy exploitation and onesidedness does reflect the courts' rhetoric, which is cast in terms of whether or not such provisions are "penalties" and therefore suggests a concern with advantage taking and oppression. In fact, however, the justification for the special scrutiny is not that liquidated damages provisions are specially amenable to advantage taking and oppression, but that such provisions are systematically more likely to be the products of the limits of cognition than performance terms, that is, terms that specify the performance each party is to render.

To begin with, bounded rationality and rational ignorance have a special bearing on liquidated damages provisions. Contracting parties will normally find it relatively easy to evaluate proposed performance terms, such as subject matter, quantity, and price. In contrast, at the time the contract is made it is often impracticable, if not impossible, to imagine all the scenarios of breach. Similarly, the inherent complexity of determining the application of a liquidated damages provision to every possible breach scenario is often likely to exceed actors' calculating capabilities.

Even on the doubtful assumption that a party could imagine all breach scenarios and calculate the application of a liquidated damages provision to every possible breach, the benefits of extensive search and information processing on these issues will often seem to be very low as compared to the costs. A party who contracts to buy or sell a commodity normally expects to perform. Accordingly, the benefits of deliberating very carefully on performance terms are compelling, and the costs of such deliberation are usually not undue in relation to the benefits. In contrast, the same party will not normally expect that a liquidated damages provision will ever come into play against him-partly because he intends to perform, and partly because experience will tell him that in general there is a high rate of performance of contracts. ${ }^{89}$ For example, if contracts are performed at least 95 percent of the time (which observation suggests is likely), all the costs of processing the more remote applications of a liquidated damages provision would have to be taken into account, but the benefits of such processing would have to be discounted by 95 percent. The resulting cost-benefit ratio will often provide a substantial disincentive for processing every possible application of a liquidated damages provision, even if it were in fact possible to imagine every such scenario. As a result, contracting parties are likely often to not even try to think liquidated damages provisions through, and are therefore unlikely to fully understand the implications of such provisions.

The problem of disposition also bears significantly on liquidated damages provisions. Because actors tend to be unrealistically optimistic, a contracting party will probably believe that his performance is more likely, and his breach less likely, than is actually the case. Accordingly, unrealistic optimism will

89. See Melvin A. Eisenberg, The Principle of Hadley v. Baxendale, 80 CAL. L. Rev. 563, 593 (1992). 
reduce even further the deliberation that actors give to liquidated damages provisions.

Finally, defective capabilities have particular relevance to liquidated damages provisions. The availability heuristic may lead a contracting party to give undue weight to his present intention to perform, which is vivid and concrete, as compared with the abstract possibility that future circumstances may compel him to breach. Because a contracting party is likely to take the sample of present evidence as representative of the future, he is apt to overestimate the extent to which his present intention to perform is a reliable predictor of his future intentions. Because actors have faulty telescopic faculties, a contracting party is likely to overvalue the benefit of the prospect of performance, which will normally begin to occur in the short term, as against the cost of the prospect of a breach, which will typically occur, if at all, only down the road. Because actors tend to underestimate risks, a contracting party is likely to underestimate the risk that a liquidated damages provision will take effect.

The cases themselves provide dramatic evidence of how liquidated damages provisions are peculiarly subject to the limits of cognition. A good example is the landmark English case Kemble v. Farren. ${ }^{90}$ In this case, a performer had agreed to be the principal comedian at Covent Garden Theatre during the ensuing four seasons and to fully conform to the theater's usual regulations. The theater had agreed to pay the actor $£ 3,6 \mathrm{~s}$. 8d. every night the theater was open during the four seasons. The contract also provided that if either party failed to fulfill the agreement or any part thereof, that party would pay the other $£ 1000$. The actor breached the contract, and the theater sued for liquidated damages.

The court began by noting that liquidated damages provisions can serve valid purposes: "In many cases, such an agreement fixes that which is almost impossible to be accurately ascertained; and in all cases, it saves the expense and difficulty of bringing witnesses to that point." 91 Nevertheless, the court held that the provision in question was unenforceable. In reaching this conclusion, the court pointed out the bizarre ways the provision could operate:

[T] he clause . . . extends to the breach of any stipulation by either party. If, therefore, on the one hand, the Plaintiff had neglected to make a single payment of $£ 3,6$ s $8 d$. per day, or on the other hand, the Defendant had refused to conform to any usual regulation of the theatre, however minute or unimportant, it must have been contended that the clause in question, in either case, would have given the stipulated damages of $£ 1000.92$

It seems scarcely likely that the parties in Kemble intended their liquidated damages provision to apply to every conceivable failure to perform. Rather, it is almost certain that as a result of the limits of cognition, the parties failed to think through the scenarios under which the provision would apply.

\footnotetext{
90. 6 Bing. 141, 19 Eng. Rep. 71 (C.P. 1829).

91. 6 Bing. at 148 .

92. Id.
} 
The Lake River case, ${ }^{93}$ which occasioned Judge Posner's critique of the principle governing liquidated damages provisions, provides another example. In Lake River, Carborundum had made a contract with Lake River under which Lake River was to take Ferro Carbo, an abrasive powder used in making steel, in bulk from Carborundum, bag it, and distribute the bagged product to Carborundum's customers. To handle the Ferro Carbo, Lake River was required to install a new bagging system at a cost of $\$ 89,000$. To ensure recovery of the cost of the bagging system, Lake River insisted on a minimum-quantity-guarantee provision. The provision required Carborundum to ship 22,500 tons of Ferro Carbo to Lake River for bagging during the initial three-year term of the contract. If Carborundum failed to meet this minimum, Carborundum was to pay for the shortfall at the then-prevailing bagging rate under the contract. As Judge Posner recognized, this was essentially a liquidated damages provision. ${ }^{94}$

After the contract was signed in 1979, the demand for domestic steel, and hence for Ferro Carbo, fell dramatically. As a result, by the time the initial three years expired in late 1982, Carborundum had shipped only 12,000 of the 22,500 tons it had guaranteed. Lake River demanded payment of $\$ 241,000$, under the liquidated damages provision.

The court held that the provision was unenforceable.95 Judge Posner pointed out that Lake River had expected to make a profit of $\$ 107,000$ net of all expenses, including the cost of the bagging system, if Carborundum had shipped the full guaranteed quantity. He then demonstrated the extraordinary way the provision operated under various scenarios. For example, if Carborundum had breached the contract before shipping any Ferro Carbo, and the liquidated damages provision were enforced, Lake River would make a profit of $\$ 444,000$, or more than four times the profit it would have made if Carborundum had performed-even assuming the bagging system had a value of zero at that point. If, as actually occurred, Carborundum breached after 55 percent of the Ferro Carbo had been shipped, and the liquidated damages provision were enforced, Lake River would make a profit of $\$ 260,000$, or two-and-one-half times the profit it would have made if Carborundum had performed. In short, if the provision were enforceable it would generate damages to Lake River ranging up to 434 percent of the profits that Lake River stood to make by full performance. ${ }^{96}$

It is almost inconceivable that the parties understood and intended that the provision would operate in that way, or that Carborundum, undoubtedly the stronger party, would have agreed to the provision if it had understood how the

93. Lake River Corp. v. Carborundum Co., 769 F.2d 1284 (7th Cir. 1985).

94. Id. at 1288 ("The hardest issue ... is whether the formula in the minimum-guarantee clause imposes a penalty ... or is merely an effort to liquidate damages.").

95. Id. at 1290 .

96. Id. at 1290-91. According to Judge Posner's analysis, if the liquidated damages provision were enforced at any of various times between the beginning of Lake River's performance and nearly the end, it would generate a windfall ranging from $130 \%$ to $400 \%$ of Lake River's expected contract profits, even assuming that the bagging system had no value apart from the contract. If the bagging system were worth as little as $\$ 20,000$ at the time of breach, damages would range from $150 \%$ to $434 \%$ of expected profits. Id. 
provision operated. The overwhelming likelihood is that, as in Kemble, because of the special bite of the limits on cognition in the case of liquidated damage provisions, neither Carborundum nor Lake River managed to think through how the provision would operate under various breach scenarios.

Cases like Kemble and Lake River, which are not unique, ${ }^{97}$ forcefully illustrate that as a result of the limits of cognition, the premise underlying the bargain principle - that a contracting party will act with full cognition to rationally maximize his subjective expected utility-does not apply to liquidated damages provisions. Since the premise does not apply, neither should the principle itself. Rather, special scrutiny of liquidated damages provisions is justified because such provisions are subject to the limits of cognition in a special way.

The cognitive explanation of the liquidated damages principle is important not only because it justifies special scrutiny of liquidated damages provisions, but also because it helps shape the form that scrutiny should take. Recall that under the general formulation, a liquidated damages provision is enforceable only if: (I) actual damages are difficult to estimate, and (II) the amount fixed in the provision is a reasonable estimate of the actual loss. This general formulation leaves open two critical and parallel questions of application.

The first question concerns the meaning of requirement $I$, that actual damages are difficult to estimate. This requirement is susceptible to two very different interpretations. It may mean that the amount of actual damages, if breach should occur, is difficult to determine at the time the contract is made. Alternatively, it may mean that at the time the contract is made it is foreseeable that the amount of actual damages will be difficult to determine even after a breach occurs. I will call these alternatives the "time-of-contract" and "timeof-breach" approaches to requirement I, respectively.

The theoretical and practical differences between these two approaches are great. For example, suppose the amount of actual damages will depend on the difference between the contract price and the market price at the time of breach. Under the time-of-contract approach, requirement I will almost always be satisfied, because a future market price can almost never be predicted when a contract is made. In contrast, under the time-of-breach approach, requirement I will almost never be satisfied, because market price is usually easy to determine at the time of breach.

The ambiguity of requirement $I$ is manifested by a split in the case law. For example, in Lee Oldsmobile, Inc. v. Kaiden ${ }^{98}$ the court invoked a time-ofbreach approach to invalidate a liquidated damages provision. Kaiden sent a $\$ 5000$ deposit on the purchase of a car to Lee, a Rolls-Royce dealer. Lee then

97. See, e.g., Meltzer v. Old Furnace Dev. Corp., 254 N.Y.S.2d 246, 249, 44 Misc. 2d 552, 553 (1964) (invalidating mortgage provisions that rendered mortgagors liable for an additional $25 \%$ of mortgage debt for default, because a default of one day would result in the same damages as a default of several months); Alvord v. Banfield, 85 Or. 49, 58-59, 166 P. 549, 552 (1917) (holding that a lease provision requiring payment of $\$ 2500$ for any breach, regardless of magnitude, is a penalty clause); Stewart v. Basey, 150 Tex. 666, 671, 245 S.W.2d 484, 487 (1952) (holding that a damage stipulation which "was not carefully drawn" should not bind the parties).

98. 32 Md. App. 556, 363 A.2d 270 (1976). 
sent an order form to Kaiden, which Kaiden signed and returned. The order form contained a clause that allowed Lee to retain any cash deposit made by the purchaser as liquidated damages if the purchaser refused to accept delivery of the car. A dispute arose concerning the date of delivery. Kaiden notified Lee that she had purchased another Rolls elsewhere, canceled her order, declined to accept the car after having been notified that it was ready for delivery, and demanded the return of her deposit. Lee refused. Kaiden then brought suit to recover the deposit.99 The court adopted the time-of-breach approach to requirement I and held that Kaiden was entitled to recover the amount of her deposit, minus actual damages, "because at the time the contract was made, it was clear that the nature of any damages which would result from a possible future breach was such that they would be easily ascertainable."100

In contrast, in Hutchison v. Tompkins ${ }^{101}$ the Florida Supreme Court adopted the time-of-contract approach to requirement $I$. The complaint alleged that Buyers agreed to purchase land for $\$ 125,000$, and deposited $\$ 10,000$ in cash with an escrow agent toward the purchase price. The contract contained a liquidated damages provision under which Sellers could elect to retain the deposit if Buyers failed to perform. Sellers claimed that Buyers breached the contract by refusing to complete the purchase, and sued for the amount of the deposit.102 The trial court dismissed the complaint on the ground that the liquidated damages provision was invalid. ${ }^{103}$

The Florida Supreme Court began by reexamining two of its earlier decisions. In Pembroke v. Caudill104 the court had followed the time-of-breach approach and held that if damages are ascertainable at the time of breach, a liquidated damages provision will be treated as a penalty even if damages were difficult to estimate at the time the contract was made. ${ }^{105}$ In contrast, in $\mathrm{Hy}$ man v. Cohen ${ }^{106}$ the court had followed the time-of-contract approach, and held that requirement I was satisfied if actual damages were not readily ascertainable at the time the contract was made. ${ }^{107}$ In Hutchison, the court followed Hyman rather than Pembroke.

Damages, especially in real estate transactions, are nearly always ascertainable at the time a contract is breached, because, as the Pembroke opinion points out, the measure of damages involves determining the difference between the agreed purchase price and the market value of the land as of the date of breach. Accordingly, the rule in Pembroke must have, when followed in letter and spirit ... a chilling effect on contract negotiations where the parties wish to include a provision for liquidated damages. ${ }^{108}$

99. 363 A.2d at 271.

100. id at 274.

101. 259 So. $2 d 129$ (Fla. 1972).

102. Id. at $129-30$.

103. Id. at 130 .

104. 160 Fla. 948, 37 So. $2 d 538$ (1948).

105. 37 So. $2 \mathrm{~d}$ at $540-41$, discussed in Hutchison, 259 So. $2 \mathrm{~d}$ at 131.

106. 73 So. 2d 393 (Fla. 1954).

107. Id. at 400-01, discussed in Hutchison, 259 So. 2d at 131-32.

108. Hutchison, 259 So. $2 d$ at 132. 
Requirement $\mathrm{I}$-that the amount fixed in the liquidated damages provision is a reasonable estimate of the actual loss-is subject to the same ambiguity as requirement I. Requirement II may mean any of the following: (A) that the liquidated damages must be a reasonable estimate of probable loss, looking forward from the time the contract is made; (B) that the liquidated damages must not be disproportionate to the loss that is actually sustained; (C) that the liquidated damages must satisfy either test $A$ or test $B$; or $(D)$ that the liquidated damages must satisfy both test $A$ and test $B$. I will call test $A$ a purely "forward-looking" standard, and tests B, C, and D "second-look" standards.

The traditional view of requirement II was that liquidated damages need only satisfy the forward-looking standard. This view was consistent with the position that the justification for giving special scrutiny to liquidated damages provisions is that such provisions are especially subject to blameworthy exploitation and one-sidedness, because whether there was blameworthy exploitation and one-sidedness should be judged as of the time the contract is made. ${ }^{109}$ In contrast, the cognitive justification for special scrutiny of liquidated damages provisions suggests a second-look standard-comparing liquidated damages with the actual loss-because a gross discrepancy between forecast and result suggests that the liquidated damages provision was a product of limited or defective cognition.

Despite the traditional emphasis on the forward-looking standard, the second-look standard, which is supported by the cognitive justification, seems to be emerging law. As a predictive matter, it is highly likely that even courts that profess a purely forward-looking standard will nonetheless take a second look at a liquidated damages provision in light of the loss actually sustained. ${ }^{110}$ Furthermore, formal doctrine itself appears to be coming around to a second-look standard, although the cases have not been consistent on this point. ${ }^{111}$

Several leading authorities have formalized a rule that liquidated damages provisions can be upheld on a second-look basis. Under this rule, courts may uphold liquidated damages that reasonably approximate the damages actually sustained, even if, at the time the contract was made, the liquidated damages were not a reasonable estimate of the probable loss. For example, section 2718(1) of the Uniform Commercial Code provides that "[d]amages for breach

109. See, e.g., United States v. Bethlehem Steel Co., 205 U.S. 105, 119-21 (1907) (upholding a contract provision, negotiated during a war and reasonable ex ante, stipulating damages for late delivery of guns, even though the end of the war prior to the delivery date eliminated the possibility of losses); see also Southwest Eng'g Co. v. United States, 341 F.2d 998, 1003 (8th Cir. 1965) (holding that the situation at the time of the contract is controlling in determining the reasonableness of liquidated damages), cert. denied, 382 U.S. 819 (1965).

110. Sweet concludes that when courts decide whether to enforce a liquidated damages clause, "though the announced test is look-forward, what counts is the convenience and efficiency by which actual damages can be measured at trial." Justin Sweet, Liquidated Damages in California, 60 CAL. L. REv. 84, 136 (1972). Sweet concludes that when directly faced with the question, most Califomia courts will not knowingly enforce a liquidated damages clause where there is no actual damage. Id. at 138; see also Freedman v. Rector, 37 Cal. 2d 16, 21-22, 230 P.2d 629, 632 (1951) (holding that any provision that leads to forfeiture without regard to the actual damage suffered would be an unenforceable penalty) (citing Ebbert v. Mercantile Trust Co., 213 Cal. 496, 499, 2 P.2d 776, 777 (1931)).

111. See Rea, supra note 84 , at 150 (citing cases). 
by either party may be liquidated in the agreement but only at an amount which is reasonable in the light of the anticipated or actual harm caused by the breach." 112 Similarly, comment $b$ to Restatement Second section 356 states that "[t]he amount fixed is reasonable to the extent that it approximates the actual loss that has resulted from the particular breach, even though it may not approximate the loss that might have been anticipated under other possible breaches."113

That courts may take a second look for the purposes of upholding a liquidated damages provision implies that courts may take a second look for all purposes. At least one court has interpreted U.C.C. section 2-718 just this way, 114 and Restatement Second adopts this position explicitly: "If . . . the difficulty of proof of loss is slight, less latitude is allowed in [the] approximation [of anticipated or actual harm]. If, to take an extreme case, it is clear that no loss at all has occurred, a provision fixing a substantial sum as damages is unenforceable." 115

The second-look standard is also well supported by case law. ${ }^{116}$ Recall that in Hutchison v. Tompkins, the Florida court, following an earlier Florida deci-

112. U.C.C. \$ 2-718(1) (1987) (emphasis added).

113. Restatement (Second) of Contracts $\& 356 \mathrm{cmt}$. $b$ (1979) (emphasis added). The comment goes on to state that this is actually an either/or approach (test C): "Furthermore, the amount fixed is reasonable to the extent that it approximates the loss anticipated at the time of the making of the contract, even though it may not approximate the actual loss." Id.

114. In Equitable Lumber Corp. v. IPA Land Devel. Corp., 38 N.Y.2d 516, 344 N.E.2d 391, 381 N.Y.S.2d 459 (1976), the court stated that

[U.C.C.] section 2-718 does, in some measure, signal a departure from prior law which considered only the anticipated harm at the time of contracting since that section expressly contemplates that a court may examine the "actual harm" sustained in adjudicating the validity of a liquidated damages provision. Thus, decisions which have restricted their analysis of the validity of liquidated damages clauses solely to the anticipated harm at the time of contracting have, to this extent, been abrogated by the Uniform Commercial Code in cases involving transactions in goods.

344 N.E.2d at 395 (citations omitted).

115. Restatement (SECOND) OF Contracts $\$ 356 \mathrm{cmt} . b$ (1979). Illustrations 3 and 4 to $\S 356$ provide:

3. A contracts to build a grandstand for B's race track for $\$ 1,000,000$ by a specified date and to pay $\$ 1,000$ a day for every day's delay in completing it. A delays completion for ten days. If $\$ 1,000$ is not unreasonable in the light of the anticipated loss and the actual loss to $B$ is difficult to prove, $A$ 's promise is not a term providing for a penalty and its enforcement is not precluded....

4. The facts being otherwise as stated in Illustration 3, B is delayed for a month in obtaining permission to operate his race track so that it is certain that $\mathrm{A}^{\prime} \mathrm{s}$ delay of ten days caused him no loss at all. Since the actual loss to B is not difficult to prove, A's promise is a term providing for a penalty and is unenforceable....

Id. cmt. $b$ illus. 3-4.

116. See, e.g., Colonial at Lynnfield, Inc. v. Sloan, 870 F.2d 761, 765 (1st Cir. 1989) (invalidating a liquidated damages provision because no actual damage occurred, although the damage estimate was reasonable at the time the contract was made); Northwest Fixture Co. v. Kilbourne \& Clark Co., 128 F. 256,261 (9th Cir. 1904) (denying recovery under a liquidated damages provision to a company that sustained no actual damages); Vines v. Orchard Hills, Inc., 181 Conn. 501, 511, 435 A.2d 1022, 1028 (1980) (considering actual damages at the time of breach in determining the validity of a liquidated damages clause); Norwalk Door Closer Co. v. Eagle Lock \& Screw Co., 153 Conn. 681, 688-89, 220 A.2d 263, 268 (1966) (invalidating liquidated damages because no actual damages occurred); Huntington Coach Corp. v. Board of Educ., 372 N.Y.S.2d 717, 719, 49 A.D.2d 760, 761 (App. Div. 1975) (refusing to enforce \$100-per-day liquidated damages for failure to provide school-bus services to a 
sion in Hyman, adopted the time-of-contract approach to requirement I. However, the court balanced this time-of-contract approach to requirement I by holding that the standard that governs requirement II is the second-look standard, that the liquidated damages must not be disproportionate to the loss actually sustained.

The better resuit, in our judgment . . . is to allow the liquidated damage clause to stand if the damages are not readily ascertainable at the time the contract is drawn, but to permit equity to relieve against the forfeiture if it appears unconscionable in light of the circumstances existing at the time of breach. For instance, assume a situation in which damages were not readily ascertainable at the time the contract was drawn, and the parties agreed to a liquidated damage provision of $\$ 100,000$. Purchaser later repudiated the contract; vendor resold the land to another party, which because of fluctuations in the real estate market, resulted in a loss to himself of only $\$ 2,000$. In such a case a court following the Hyman theory would allow the liquidated damage clause to stand, because damages were not readily ascertainable at the time of drawing the contract, but would, as a court of equity, relieve against the forfeiture as unconscionable. ${ }^{117}$

Although the court used the language of unconscionability, unconscionability is not really apt to describe the second-look standard the court adopted. This is so both because in the court's hypothetical there is nothing to suggest exploitation or other unfair conduct, and because the principle of unconscionability is traditionally and properly reserved for improper conduct at the time a contract is formed. ${ }^{118}$ A second-look standard for liquidated damages provisions is justified not because a second look may show that a provision was unconscionable, but because it may show that the provision was in all likelihood the product of defective cognition.

Under a cognitive approach to the liquidated damages principle, therefore, courts should formulate and apply the principle as follows: If, in the breach

school district for a five-day period where the district had not sought other transportation and the bus company had not billed the district for the period), aff'd, 40 N.Y.2d 892, 357 N.E.2d 1017, 389 N.Y.S.2d 362 (1976); Kenneth W. Clarkson, Roger L. Miller \& Timothy J. Muris, Liquidated Damages v. Penalties: Sense or Nonsense?, 1978 Wis. L. Rev. 351, 380 ("In most cases that declared actual damages to be irrelevant ... the clauses were reasonable ex ante and, given the difficulty in measuring actual damages, not unreasonable ex post. Further, in numerous cases where the clause was clearly no longer reasonable ex post, the court refused enforcement.") (footnotes omitted); Schwartz, supra note 88 , at 369 ("Courts will not enforce liquidated damage clauses when [the] stipulated sum exceeds ... the actual harm that breach tumed out to cause."); see also Massman Constr. Co. v. City Council, 147 F.2d 925, 927 (5th Cir. 1945) (refusing to allow liquidated damages in part because the city did not suffer any damages from bridge completion delays, because of even longer delays in road construction). But cf. Califomia \& Hawaiian Sugar Co. v. Sun Ship, Inc., 794 F.2d 1433, 1435-37 (9th Cir. 1986) (permitting liquidated damages although plaintiff suffered minimal actual damages due to a concurrent breach by a third party), cert. denied, 484 U.S. 871 (1987); McCarthy v. Tally, 46 Cal. 2d 577, 586, 297 P.2d 981, 987 (1956) (holding that no actual damage is necessary in order to recover under a liquidated damages provision); Leeber v. Deltona Corp., 546 A.2d 452, 454-56 (Me. 1988) (allowing liquidated damages because the amount did not shock the senses despite the lack of actual damages).

117. Hutchison v. Tompkins, 259 So. 2d 129, 132 (Fla. 1972).

118. See, e.g., Restatement (SECOND) OF ConTRACTs $\$ 208$ (1979) ("If a contract or term thereof is unconscionable at the time the contract is made a court may refuse to enforce the contract ....") (emphasis added). 
scenario that has actually occurred, liquidated damages are significantly disproportional to real losses (that is, losses in fact, not simply legal damages), the provision is unenforceable unless it is established that the parties had a specific and well-thought-through intention that the provision apply in a scenario like the one that actually occurred.

I will call this approach the cognitive interpretation of the liquidated damages principle. This interpretation, which is consistent with the emerging law supporting a second-look approach, has several important implications.

One implication is that the mere fact that liquidated damages are intended as a penalty should not make the provision unenforceable. Feller offers a good example of such a case:

Many of the contractual rules governing employee compensation include penalties and are intentionally negotiated as such. For example, premium pay for hours worked on Saturday and Sunday, or before and after the normally scheduled hours, is often intended to penalize improper scheduling. The punitive character of these compensation rules is evidenced by the magnitude of such weekend and overtime premiums as compared to the much smaller premiums for shift work in the same industry, or by comparing the premiums paid for Sunday work in continuous-process industries where Sunday work is expected with the premiums paid in all other industries. ${ }^{119}$

A second implication of the cognitive interpretation of the liquidated damages principle is that requirement I-that actual damages are difficult to estimate-should be dropped, because that requirement is irrelevant to determining whether a liquidated damages provision is a product of the limits of cognition. This modification of the liquidated damages principle is not as drastic as it might seem. Cases like Hutchison, which hold that the application of requirement $I$ is based on a time-of-contract approach, drop that requirement in all but form, because at the time a contract is made it is almost always impossible to determine what the actual damages will be at the time of breach.

A third implication of the cognitive interpretation of the liquidated damages principle is that the courts should normally take a less searching look at liquidated damages provisions that take the form of an advance deposit that is made subject to forfeit in the event of complete nonperformance. Such a deposit is less likely to involve cognitional problems than a simple liquidated damages provision, partly because the act of putting down money powerfully focuses the mind, and partly because a deposit is instantiated, concrete, vivid, and present.

It needs to be emphasized that the cognitive interpretation of the liquidated damages principle allows wide scope to liquidated damages provisions. Under that interpretation, a liquidated damages provision should relieve the plaintiff of the burden of proving damages, by shifting to the defendant the burden of establishing that the liquidated damages provision is unenforceable. ${ }^{120}$ Further-

119. David E. Feller, The Remedy Power in Grievance Arbitration, 5 INDUs. REL. L.J. 128, 133 (1982) (footnote omitted).

120. See James Patrick Fenton, Note, Liquidated Damages as Prima Facie Evidence, 51 IND. L.J. 189, 197-207 (1975) (arguing that when breach has been shown but damages are difficult to ascertain, a rebuttable presumption should arise that the predetermined amount of liquidated damages is correct). 
more, a liquidated damages provision should allow the plaintiff to recover actual losses that would not otherwise be compensable because the legal rules governing contract damages do not provide full compensation. For example, a liquidated damages provision should be enforceable if it covers nonpecuniary losses, losses whose recovery would otherwise be barred by the principle of Hadley v. Baxendale, ${ }^{121}$ losses that would otherwise be too uncertain, or litigation expenses, such as attorneys' fees. Moreover, a liquidated damages provision should be enforced if the actual loss is only determinable within a wide range, and the amount fixed by the provision is within that range.

In summary, the blameworthiness rationale of the liquidated damage principle is difficult to support. Because that rationale is weak if not incorrect, the case law is often incoherent: Like cases are often decided differently, and results are often difficult to predict. The cognitive justification of the liquidated damages principle drives to the surface the real reason to give special scrutiny to liquidated damages provisions, and prescribes the form that scrutiny should take.

\section{B. The Excuse of Express Conditions}

Just as contract law has adopted a principle of special scrutiny of liquidated damages provisions, so too has it adopted a principle of special scrutiny of express conditions. A promise involves a commitment by a party that some specified state of events will or will not occur. An express condition qualifies a contractual duty by providing either that a party is not obliged to perform the duty unless a specified event occurs or fails to occur, or that the duty will be suspended or terminated if a specified event occurs or fails to occur. Thus, an express condition does not itself involve a commitment, unless it is doing double duty as both an express condition and a promise. ${ }^{122}$

Promises and express conditions have much different consequences. A party normally can enforce a contract if he has substantially performed his promises, even though he has not perfectly performed. In contrast, a party normally cannot enforce a contract for breach of a promise unless the conditions to the other party's performance have been perfectly fulfilled. A promisee may recover damages upon breach of a promise by the promisor, but normally cannot terminate the contract unless the breach was material. In contrast, if $A$ fails to perfectly fulfill a condition to B's obligation to perform, then at least in principle B can terminate the contract even if the failure is insignificant. Termination for nonfulfillment of an express condition is an especially severe sanction, because A may lose not only the value of the contract but the value of his prior performance, subject to possible recovery for any benefit conferred.

The strict rule that conditions must be perfectly fulfilled is qualified in several ways. Most notable is a principle of special scrutiny, codified as follows in

121. 9 Ex. 341, 354, 156 Eng. Rep. 145 (1854) (holding that the damages awarded for breach of contract must either arise naturally from the breach or be foreseeable at the time of the contract). See generally Goetz \& Scott, supra note 87.

122. In some cases, however, a court may infer a promise from a condition. 
Restatement Second section 229: "To the extent that the non-occurrence of a condition would cause disproportionate forfeiture, a court may excuse the nonoccurrence of that condition unless its occurrence was a material part of the agreed exchange." 123

The comment to section 229 defines "forfeiture" as "the denial of compensation that results when the obligee loses his right to the agreed exchange after he has relied substantially, as by preparation or performance on the expectation of that exchange." The comment continues:

In determining whether the forfeiture is disproportionate, a court must weigh the extent of the forfeiture by the obligee against the importance to the obligor of the risk from which he sought to be protected and the degree to which that protection will be lost if the non-occurrence of the condition is excused to the extent required to prevent forfeiture. ${ }^{124}$

The comment also makes clear that unlike a determination of unconscionability, application of the principle embodied in section 229 depends on the actual result of enforcing the provision, rather than on the conduct of the parties at the time the contract is formed. ${ }^{125}$ Thus, the principle is explicitly based on a second-look approach.

The cases amply support the principle of special scrutiny of express conditions. For example, in Jacob \& Youngs, Inc. v. Kent, ${ }^{126}$ plaintiff agreed to build a country residence for defendant. One of the plumbing specifications provided that "[a]ll wrought iron pipe must be ... of the grade known as 'standard pipe' of Reading manufacture."127 Final payment was conditioned upon a certificate of completion to be given by defendant's architect. Some of the pipe plaintiff used was of Cohoes manufacture, although identical to Reading pipe, and defendant's architect refused to give plaintiff a certificate of completion. Plaintiff sued for the final payment. ${ }^{128}$ Justice Cardozo, writing for the New York Court of Appeals, held that plaintiff was entitled to the payment,

123. Restatement (SECOND) OF Contracts $\$ 229$ (1979). Under a corollary principle expressed in $\S 227(1)$, the courts put a thumb on the scales by favoring the interpretation of a contractual term as a promise if interpreting the term as a condition will increase the risk of forfeiture. See id. $\$ 227(1) \mathrm{cmt}$. b.

124. Id. $\S 229 \mathrm{cmt} . b$.

125. The comment states:

Although both this Section and $\S 208$, on unconscionable contract or term, limit freedom of contract, they are designed to reach different types of situations. While $\S 208$ speaks of unconscionability "at the time the contract is made," this Section is concerned with forfeiture that would actually result if the condition were not excused. It is intended to deal with a term that does not appear to be unconscionable at the time the contract is made but that would, because of ensuing events, cause forfeiture.

Id. cmt. $a$. In this respect, $\S 229$ also differs from $\S 227$, which is based on the risk of forfeiture at the time of formation. Id. $\S 227 \mathrm{cmt} . b$.

126. 230 N.Y. 239,129 N.E. 889 (1921).

127. 129 N.E. at 890.

128. Id.; see also Richard Danzig, The Capabitty Problem in Contract law: Further Readings on WeLL-KNOWN CASEs 108-12 (1978) (excerpting the actual contract at issue in Jacob \& Youngs); E.A. Farnsworth \& W. Young, Contracts-CAses and Materials 502 n.a (4th ed. 1988) (same). 
with only an offset for the difference in value between Reading and Cohoes pipe, "which would be either nominal or nothing." 129

Similarly, in Hegeberg v. New England Fish Co., ${ }^{130}$ the Washington Supreme Court held that an insignificant departure from a time condition did not excuse nonperformance. The court noted that it had "not hesitated to grant relief from express conditions in contracts, where great injustice and undue hardship would result from strict enforcement of the terms of the agreement."131 In Holiday Inns of America, Inc. v. Knight, ${ }^{132}$ the California Supreme Court also granted relief from the operation of a time condition. B had entered into an option contract with $S$ for the purchase of property. The contract provided for an initial payment of $\$ 10,000$ and for four additional payments of $\$ 10,000$, to be paid to $S$ on July 1 of each year. Under the contract, failure to make payment on or before the specified date resulted in cancelation of the option. B made timely payments for two years, and made expenditures that substantially increased the value of the option property. In year three, however, $S$ did not receive B's check until July 2 . S returned the check, stating that the option was canceled. ${ }^{133}$ The court refused to enforce the cancelation provision. ${ }^{134}$

The principle that governs the review of express conditions is very similar to the principle that governs the review of liquidated damages provisions. Both principles concern sanctions. Both principles allow the courts to override bargained-for provisions even in the absence of unconscionability. Both principles turn on a second look. And just as the special principle concerning liquidated damages provisions is traditionally supported by a rhetoric that centers on the idea of penalty, the principle governing the excuse of express conditions is traditionally supported by a rhetoric that centers on the idea of forfeiture..$^{135}$

Most importantly, the principle that governs the excuse of express conditions, like the principle that governs the review of liquidated damages provisions, is best explained not by the traditional rhetoric, but by the limits of cognition. Were it not for the limits of cognition, the law should no sooner excuse an express condition than it should refuse to enforce performance terms that turn out to be extremely disadvantageous to one party. However, the limits of cognition operate with respect to express conditions in a manner that closely parallels the operation of those limits with respect to liquidated damages provisions.

129. Jacob \& Youngs, 129 N.E. at 891.

130. 7 Wash. 2d 509, 526, 110 P.2d 182, 189 (1941).

131. 110 P.2d at 188 .

132. 70 Cal. 2d 327, 450 P.2d 42, 74 Cal. Rptr. 722 (1969).

133. 450 P.2d at 43 .

134. Id. at 44 ("[T] $]$ he question is not whether the exercise of the option was timely, but whether the right to exercise the option in the future was forfeited by a failure to pay the consideration for that right precisely on time.") (emphasis added). For similar treatment of express conditions, see, e.g., Elliott v. Snyder, 246 S.C. 186, 186, 143 S.E. 2 d 374, 375 (1965) (refusing to void a contract despite a delayed installment payment).

135. See, e.g., Jones Assocs., Inc. v. Eastside Properties, Inc., 41 Wash. App. 462, 469, 704 P.2d 681,686 (1985) (holding that a requirement of plat approval should be read as a promise, not a condition, because the law disfavors forfeiture). 
First, bounded rationality will often limit the full comprehension of express conditions. The costs of determining the various ways an express condition may fail to be fulfilled are very high, because at the time of contracting a party cannot efficiently conceive of every contingency under which nonfulfillment may occur. Indeed, not every contingency may be effectively conceivable at the time of contracting. Moreover, the benefits of incurring these costs are likely to seem dubious to a party on the verge of making a contract. Just as a liquidated damages provision bites only if a party fails to perform a promise, so an express condition bites only if it is not fulfilled. Because parties normally expect to fulfill conditions, the consequences of nonfulfillment will seem remote at the time the contract is made. Accordingly, a party is likely to view the costs of fully deliberating on the operation of an express condition as unduly high in light of the significant probability that the provision will not come into play. Although parties may give more deliberation to an express condition than to a liquidated damages provision because the operation of an express condition is apt to be more specific, parties may also give express conditions less deliberation because they may be unaware of the potentially draconian legal sanctions for insignificant variations from perfect fulfillment of a condition. Indeed, most parties may not even be aware of the legal distinction between promises and express conditions or of the consequences of that distinction, which often present extremely difficult questions even for courts. ${ }^{136}$

The problem of disposition also has a special impact on express conditions. Because actors are unduly optimistic, a contracting party is likely to believe that fulfillment of an express condition is more likely, and nonfulfillment less likely, than is actually the case.

Finally, defects in capability are likely to discourage parties from focusing on express conditions. The availability heuristic is likely to lead a contracting party to give undue weight to his present intention to fulfill an express condition, which is vivid and concrete, as compared to the possibility that future circumstances may lead to nonfulfillment, which is pallid and abstract. Moreover, the tendency to underestimate risks will likely cause a contracting party to underestimate the risk that an express condition will not be fulfilled.

As with liquidated damages, the cases illustrate how express conditions are vulnerable to defective cognition. In many cases, it seems clear that one or both parties failed to think through how a condition would operate. For example, a pipe wholesaler interviewed in connection with Jacob \& Youngs v. Kent explained that in the prewar period, genuine wrought iron pipe was exclusively manufactured by four companies, including Reading, Cohoes, Byers, and Southchester-each of which produced pipe of absolutely identical quality and price. ${ }^{137}$ In these circumstances, the common practice of naming a manufacturer was apparently intended not to distinguish among the four companies but

136. See, e.g., Brown-Marx Assocs., Ltd. v. Emigrant Sav. Bank, 703 F.2d 1361 (11th Cir. 1983) (holding that a builder's failure to fully meet a minimum-rental express condition relieved a bank from its obligation to furnish a loan); In re Carter's Claim, $390 \mathrm{~Pa}$. 365, 134 A.2d 908 (1957) (enforcing the traditional distinction between promises and conditions).

137. DanzIG, supra note 128 , at 121 (quoting an unnamed pipe wholesaler). 
to ensure that a contractor would not pass off, as wrought iron pipe, imitation pipe produced by a company other than one of the four wrought iron manufacturers. ${ }^{138}$ It therefore seems highly unlikely that if the parties had thought the matter through, they would have agreed that if the contractor installed one of the three brands of pipe that were identical to Reading pipe, all remaining payments on the house could be withheld. Similarly, it seems highly unlikely that the optionee in Holiday Inn would have agreed that if he missed a payment by one day, he would lose the value of all the payments and improvements he had previously made. ${ }^{139}$

It might be argued that even if one party, A, would be reluctant to agree to a condition if he fully understood that he would face draconian sanctions for insignificant variations from perfect fulfillment, the other party, B, would insist on those sanctions. That is possible, but unlikely. If both parties fully understand the operation of the condition, then the price B pays for A's performance will be higher than it otherwise would be, to reflect A's additional risks. Given perfect knowledge by both parties, B would probably prefer to pay less, without the power to impose draconian sanctions for imperfect fulfillment of the condition, than to pay more with that power.

Because the principle governing the excuse of express conditions to prevent forfeiture is best justified by the limits of cognition, that principle should be interpreted in a manner parallel to the cognitive interpretation of the liquidated damages principle: If, in the scenario of imperfect fulfillment that actually occurred, a requirement of perfect fulfillment would result in a substantial loss to one party that is significantly out of proportion to the interest of the other in perfect fulfillment, and if the requirement of perfect fulfillment under that scenario appears to be one to which the parties would not have agreed if they had specifically adverted to the actual scenario, courts should not require perfect fulfillment unless it is established that the parties had a specific and wellthought-through intention that perfect fulfillment be required in a scenario like the one that actually occurred.

\section{Form Contracts}

The problems raised by the use of form contracts have been a major preoccupation of contract law scholars for the past forty years. The primary areas of concern have been the enforceability of preprinted terms and the import of preprinted terms in determining whether a form sent in response to an offer constitutes an acceptance. Both concerns rest ultimately on the limits of cognition.

To begin with, most preprinted terms are nonperformance terms that relate to the future and concern low-probability risks. Accordingly, the cognitive

138. Id. at 122. Trade bulletins of the period warned that some manufacturers of cheaper pipe sold their products under misleading names such as "wrought pipe." Even pipe labeled as "genuine wrought iron pipe" could contain steel scrap, one bulletin warned; it advised buyers to specify the name of a manufacturer known not to use scrap. Id.

139. See text accompanying note 132 supra. 
problems associated with liquidated damages provisions and express conditions, including bounded rationality, optimistic disposition, systematic underestimation of risks, and undue weight on the present as compared with the future, apply as well to most preprinted terms.

Of these, the phenomenon of rational ignorance plays a particularly powerful role. Call a party who prepares a form contract a form giver, and a party who receives a form contract a form taker. A form giver typically offers a package consisting of a physical commodity (broadly defined to include goods, realty, and services) and a form contract that states the terms on which the physical commodity is sold. Each part of the package, in turn, consists of a number of subparts: The commodity has physical attributes, such as size, shape, and color; the form contract has business and legal attributes, such as price, quantity, and limitations on remedies. ${ }^{140}$

To make an optimum substantive decision, the form taker would, at a minimum, carefully deliberate on the legal attributes of each form contract that is coupled with a physical commodity he is considering. Analyzing legal attributes in this manner, however, will often be unduly costly. First, a form contract often contains a very large number of legal terms. Form insurance contracts, for example, typically include thirty, forty, or more terms. Moreover, the meaning and effect of the preprinted provisions will very often be inaccessible to laypersons. In part, this is because the terms are often written in exceedingly technical prose. Even if the terms are written clearly, however, the form taker usually will be unable fully to understand their effects, because preprinted terms characteristically vary the form taker's baseline legal rights, and most consumers do not know their baseline rights.

Williams v. Walker-Thomas Furniture Co. ${ }^{141}$ is a good example of both problems. A consumer regularly purchased furniture and home appliances from a seller on installment credit. Each purchase agreement contained the following preprinted provision:

[T] he amount of each periodical installment payment to be made by [purchaser] to the Company under this present lease shall be inclusive of and not in addition to the amount of each installment payment to be made by [purchaser] under ... prior leases, bills or accounts; and all payments now and hereafter made by [purchaser] shall be credited pro rata on all outstanding leases, bills and accounts due the Company by [purchaser] at the time each such payment is made. ${ }^{142}$

The immediate but obscure effect of this provision was that the seller retained title to each item purchased under a contract until the buyer finished paying in full for all items purchased under all contracts, even though the balance due on any particular item might be worked down to a few cents, as in-

140. In certain cases, such as insurance, the relevant commodity consists of business and legal attributes. The existence of such cases does not affect the analysis.

141. 350 F.2d 445 (D.C. Cir. 1965).

142. Id. at 447 (bracketed material (except first) and emphasis in Williams). 
deed it was in Williams. ${ }^{143}$ The effects of the provision on the buyer's baseline legal rights were even more obscure, and undoubtedly were unknown to the buyer: Until the buyer brought her total unpaid balance to zero, the seller could repossess any and every item purchased under any and every contract through summary process under the replevin statute, circumventing the normal process of a full trial. Moreover, by virtue of the provision no item the buyer purchased under any contract would fall within the protection of statutes exempting defined classes of property from attachment to satisfy a judgment. ${ }^{144}$

Despite the significance of this provision, few laymen would have understood all or even any of its implications. Even legal experts often can't understand the preprinted terms of form contracts. During the oral argument of Gerhardt v. Continental Insurance Cos. ${ }^{145}$ before the great New Jersey Supreme Court of the time, Chief Justice Weintraub looked at the insurance policy at issue and said, "I don't know what it means. I am stumped. They say one thing in big type and in small type they take it away." Justice Haneman added, "I can't understand half of my insurance policies." Justice Francis said, "I get the impression that insurance companies keep the language of their policies deliberately obscure."146

If all this were not enough, most form contracts are tendered by agents who have no authority to vary the preprinted terms, so that deliberating on those terms will often be pointless. ${ }^{147}$ Furthermore, form takers often encounter form contracts under circumstances that encourage the form taker to exert only minimal effort to understand the preprinted terms. Few hurried travelers, for example, will pause to read the boilerplate provisions of their car rental agreements. Just this issue drew the attention of the court in Thorton $v$. Shoe Lane Parking $L t d .{ }^{148}$ There, a form contract consisted of an automatically dispensed parking ticket incorporating conditions that were referred to in the ticket but specified only inside the garage. Lord Denning commented:

We have been referred to the ticket cases of former times .... They were concerned with railways, steamships and cloakrooms where booking clerks issued tickets to customers who took them away without reading them. In those cases the issue of the ticket was regarded as an offer by the company. If the customer took it and retained it without objection, his act was regarded as an acceptance of the offer. These cases were based on the theory that the customer, on being handed the ticket, could refuse it and decline to enter into a contract on those terms. He could ask for his money back. That theory was, of course, a fiction. No customer in a thousand ever read the conditions. If he had stopped to do so, he would have missed the train or the boat. ${ }^{149}$

143. Robert H. Skilton \& Orrin L. Helstad, Protection of the Installment Buyer of Goods Under the Uniform Commercial Code, 65 MrсH. L. REv. 1465, 1476-77 (1967).

144. See, e.g., CAL. Code Crv. Proc. \$§ 703.510-704.210 (West 1993).

145. 48 N.J. 291, 225 A.2d 328 (1966).

146. New Jersey Court Overrules Small Print in Policy, JURY Verdicts WKLY. News (Supp. to JURY VerdTCTS WKLY.), Jan. 13, 1969, at 3.

147. Michael I. Meyerson, The Efficient Consumer Form Contract: Law and Economics Meets the Real World, 24 GA. L. Rev. 583, 600 (1990).

148. [1971] 2 Q.B. 163 (Eng. C.A. 1970).

149. Id. at 169 (citations omitted). 
Lord Megaw, addressing the actual facts of Thorton, added that it did not take much imagination to picture the indignation of the garage owners "if their potential customers, having taken their tickets and observed the reference therein to contractual conditions ... were one after the other to get out of their cars, leaving the cars blocking the entrances to the garage, in order to search for, find and peruse the notices!"150

The bottom line is simple: The verbal and legal obscurity of preprinted terms renders the cost of searching out and deliberating on these terms exceptionally high. In contrast, the low probability of these nonperformance terms' coming into play heavily discounts the benefits of search and deliberation. Furthermore, the length and complexity of form contracts is often not correlated to the dollar value of the transaction. Where form contracts involve a low dollar value of performance, the cost of thorough search and deliberation on preprinted terms, let alone the cost of legal advice about the meaning and effect of the terms, will usually be prohibitive in relation to the benefits. Faced with preprinted terms whose effect the form taker knows he will find difficult or impossible to fully understand, which involve risks that probably will never mature, which are unlikely to be worth the cost of search and processing, and which probably aren't subject to revision in any event, a rational form taker will typically decide to remain ignorant of the preprinted terms. ${ }^{151}$

There is, however, a fundamental imbalance in this respect between the form taker and the form giver. For the form taker, any given form contract is normally a one-shot transaction. This is one reason why the costs of searching and deliberating on the terms or of retaining a lawyer to evaluate them will normally far exceed the benefits of search and processing. ${ }^{152}$ For the form giver, however, a form contract is a high-volume, repeat transaction. Thus, a rational form giver will spend a significant amount of time and money, including money for legal advice, to prepare a form contract that is optimal from his perspective. ${ }^{153}$ These asymmetrical incentives almost always work to heavily slant form contracts in favor of form givers.

Schwartz and Wilde have argued that even if most form takers don't search and deliberate on preprinted terms, the quality of preprinted terms will be set appropriately as a result of competition. ${ }^{154}$ The theory is that so long as enough consumers search for optimal terms, all form givers must offer them, provided that form givers are unable to discriminate between searchers and nonsearchers. ${ }^{155}$ However, competition will not have this effect unless a significant number of form takers participate in this search. Typically that will not

150. Id. at 173.

151. Meyerson, supra note 147, at 600 .

152. Id. at 597-600.

153. Id. at 599.

154. See Alan Schwartz \& Louis L. Wilde, Intervening in Markets on the Basis of Imperfect Information: A Legal and Economic Analysis, 127 U. PA. L. REv. 630, 678-79 (1979).

155. See id. at 638 ("When the preferences of searchers are positively correlated with the preferences of nonsearchers, competition among firms for searchers should tend to protect all consumers."). 
occur, because most form takers will find it irrational to engage in search and deliberation on any given form. ${ }^{156}$

Indeed, competition is likely to degrade the quality of preprinted terms. For example, assume banks compete to attract interest-bearing checking accounts. ${ }^{157}$ In opening an account, consumers are likely to focus primarily on interest rates and activity charges. These are performance terms and are the most salient elements of such accounts. Therefore, they are highly publicized characteristics that most consumers will search for and understand. In contrast, nonperformance terms involving low-probability risks-such as terms detailing the consequences of failing to detect and promptly report an error in the monthly statement, or the penalty for overdrawing the account-are not salient to most consumers, are not usually publicized, and quietly appear only in preprinted forms. As a result, most consumers will be rationally ignorant about these terms.

Because consumers do consider interest rates and activity charges when they shop for checking accounts, any given bank has an incentive to hold down its activity charges and increase its interest rates, compensating by cutting its other costs. To cut other costs, a bank can write preprinted terms unfavorable to the form taker to govern an account's nonsalient characteristics. The bank's marginal income from checking accounts may then equal its marginal costs, as competition requires, but the preprinted terms may not reflect consumers' reasonable expectations. Indeed, the preprinted terms may well be inefficient: Consumers who were fully informed might have placed a higher value on an account that carried a slightly lower interest rate or slightly higher activity charges but which offered more favorable terms for other characteristics.

Moreover, once some banks offer low-quality preprinted terms, competition will force other banks to include the same low-quality terms in their form contracts, so as not to be undercut on activity charges and interest rates. This is a special case of the market-for-lemons phenomenon: ${ }^{158}$ If, as a result of imperfect information, the market price of a product is low because of the product's perceived low quality, high-quality producers must lower quality to ensure that they will turn a profit at the low market price. As applied to form contracts, this means that competition may actually degrade preprinted terms that involve nonsalient risks. ${ }^{159}$

156. This is true of prominent law and economics scholars, as well as less sophisticated consumers. According to an informal survey by Cooter and Ulen at a law and economics gathering, almost none of those surveyed knew the specific terms of their checking account agreements, and almost none ever balanced their checkbooks. ROBERT CoOTER \& THOMAS S. Ulen, LAw AND ECONOMICs 31 (2d ed. forthcoming 1995).

157. The following passage draws on an example discussed in Melvin Aron Eisenberg, The Structure of Corporation Law, 89 CoLUM. L. REv. 1461, 1520-21 (1989).

158. See generally George A. Akerlof, The Market for "Lemons": Quality Uncertainty and the Market Mechanism, 84 Q.J. Econ. 488 (1970) (arguing that in markets in which buyers are skeptical about the quality of goods, sellers have an incentive to lower the quality of their products).

159. See generally Meyerson, supra note 147, at 603-08. As Meyerson explains,

Consumers who are unaware of risks will not seek or choose contracts that allocate those risks

to the seller, even when the extra cost for shifting the risk is less than the savings to the consumer. Because consumers are "price conscious" but not "term conscious," a lower price 
The law has responded to the problem raised by the limits of cognition in the context of preprinted terms through section 2-207(1) of the Uniform Commercial Code and the common law doctrine of unfair surprise, which sharply limit the effect of such terms in the contexts of contract formation and contract enforceability, respectively.

\section{U.C.C. section 2-207(1).}

Section 2-207 of the U.C.C. addresses a problem that arises when an offeror uses a form purchase or sales order, and the offeree responds with a form of his own. (Typically, the offer is a sales order, and the response is a purchase order, or the other way around.) Under the traditional common law "mirror-image" rule, a response to an offer that was not identical to the offer in all of its terms was deemed a counteroffer, rather than an acceptance, even though the response purported to be an acceptance and the variation between the offer and the response was immaterial. Because the common law deemed the response a counteroffer rather than an acceptance, no contract was formed. ${ }^{160}$ However, if a party later tendered performance, the tender was deemed made pursuant to the response/counteroffer. If the tender was accepted, a contract was formed under the terms of the response. ${ }^{161}$ In the modern era of form purchase orders and sales orders, applying this rule would almost invariably prevent the formation of contracts through an exchange of forms, since each form giver tailors his preprinted terms solely to his own interests, and the interests of buyers and sellers will almost invariably conflict.

As applied to form contracts, the mirror-image rule defeated reasonable expectations. For the reasons discussed earlier in this Part, ${ }^{162}$ few parties read all preprinted provisions, and where the typed or handwritten terms of a responsive form that appears to be an acceptance match those in an offer, the offeror will reasonably conclude that a contract has been formed. Accordingly, U.C.C. section 2-207(1) reversed the mirror-image rule, at least as regards contracts for the sale of goods. Under that section, a "definite . . . expression of acceptance"-that is, a response by an offeree that has the look and feel of an acceptance-will operate as an acceptance even though it includes terms that materially add to or vary the terms of the offer. ${ }^{163}$ Although section 2-207(1) is not explicitly limited to form contracts and preprinted terms, it was obviously

will increase demand, but better contract terms, which are not understood, will not. Thus, uninformed consumers will actually prefer an inefficient contract, with a lower stated price but higher actual cost, to a contract that efficiently allocated risks to the seller.

Id. at 605 (footnotes omitted).

160. See, e.g., Poel v. Brunswick-Balke-Collender Co., 216 N.Y. 310, 110 N.E. 619 (1915) (holding that no contract was formed because the offeree included in its responsive form a preprinted requirement of prompt acknowledgement, and no acknowledgement was given).

161. See Richard W. Duesengerg \& Lawrence P. King, Sales and BulK Transfers Under THE UNIForm COMMercial CODE $§ 3.02$ (rev. ed. 1994).

162. See text accompanying notes 140-149 supra.

163. Section 2-207(1) provides that in contracts for the sale of goods, "[a] definite and seasonable expression of acceptance... which is sent within a reasonable time operates as an acceptance even though it states terms additional to or different from those offered or agreed upon . ..." U.C.C. $\S 2$ 207(1) (1989). U.C.C. § 2-207(2) makes clear that \$ 2-207(1) may apply even if the differences be- 
designed to deal with such contracts, ${ }^{164}$ and virtually all of the cases that have found an acceptance under this section have concerned form contracts.

Section 2-207(1) is justified by, and only by, the limits of cognition. After all, if an offeror receives a response from an offeree that the offeror knows or should know is not an acceptance, no contract will be formed no matter how immaterial the difference between the offer and the response. For example, suppose A offers to sell her house to B for $\$ 400,000$, and B responds, "I will purchase your house for $\$ 400,000$, provided that you replace the front doorknob." There would be no contract even though the price of replacing the front doorknob is minimal, because a reasonable person in the position of either $A$ or $B$ would realize that a bargain had not yet been concluded.

Similarly, no contract will be formed, even under section 2-207(1), if the parties use individualized communications, rather than preprinted forms, and it is clear that a bargain has not yet been concluded. For example, in Koehring Co. v. Glowacki, ${ }^{165}$ Koehring circulated a letter listing nine items of surplus machinery available for sale at its plant on an "as is, where is" basis. Glowacki telephoned Koehring's agent, inquiring about the price. The agent responded that Glowacki must bid $\$ 16,500$ by telegram. Glowacki sent a telegram bidding $\$ 16,500$ but also including the statement, "FOB, our truck, your plant, loaded." Koehring responded with a telegram "accepting" the bid, but restating that the machinery was sold "as is, where is." 166 Although the difference may have been minor, the court properly held that a contract had not been formed. ${ }^{167}$

In the case of form contracts, however, most offerors will rationally ignore the preprinted terms of responsive forms. Therefore, an offeror who receives a responsive form that appears to be an acceptance and whose typed-in terms match the offeror's typed-in terms will reasonably believe that a contract has been formed, despite even material differences in the preprinted terms of the offer and the response.

\section{Unfair surprise.}

The common law doctrine of unfair surprise is in many respects comparable to the rule of section 2-207(1). Under this doctrine, a contractual provision will not be enforced if one party to a prospective written contract includes a term in the writing that he knows or should know will violate the reasonable expectations that the other party has formed on the basis of such elements as the actually negotiated terms and the circumstances surrounding the transaction. ${ }^{168}$ Like U.C.C. section 2-207(1), the doctrine of unfair surprise is not limited to

tween the offer and acceptance are material, and a response can constitute an acceptance under $\S 2$ 207(1) even if it includes terms that materially diverge from the terms of the offer.

164. Id. \$ 2-207 cmt. 1 ("A frequent example ... is the exchange of printed purchase order and acceptance ... forms.").

165. 77 Wis. 2 d 497, 253 N.W.2d 64 (1977).

166. 253 N.W.2d at 68.

167. Id. at 69 .

168. See Eisenberg, supra note 157, at 1468. 
preprinted terms but usually is applied only to such terms. ${ }^{169}$ Also like section 2-207(1), the doctrine rests on a foundation of limited cognition: If form takers could be expected to read and perfectly understand the operation of preprinted terms, there could be no surprise. But while the limits of cognition are the sole basis of section 2-207(1), in the case of unfair surprise the cognitive foundation supports a superstructure of fault. At least in theory, the doctrine requires not only surprise, but unfair surprise.

Certainly, it is unfair-unconscionable-for a form giver to include in a written contract a preprinted term that he knows or should know will violate the form taker's reasonable expectations. By inserting such a term, the form giver unfairly exploits the form taker's limits of cognition. Nevertheless, fault should not be an element of the law governing the enforceability of preprinted terms. Requiring proof of fault adds an inappropriate hurdle to the form taker's case. Requiring fault can pose a problem where, as in the checking-account example, the reduction in the form giver's costs resulting from savings generated by the term is impounded in the form giver's price, so that the form taker is "paid" for being subject to the term. ${ }^{170}$ Under a fairness analysis, this might be relevant, but under a cognitional analysis, it is not.

The fault element in the doctrine of unfair surprise has also led the courts to inquire whether the relevant term was conspicuous and clearly written. In Williams v. Walker-Thomas Furniture Co., the court emphasized the importance of determining whether the term was "hidden in a maze of fine print."171 In Gerhardt v. Continental Insurance Cos., the court refused to enforce an obscurely worded exception to a comprehensive liability policy on the ground that the term was "neither conspicuous nor plain and clear."172

The problem with such an inquiry is that, for reasons already explored, most form takers will be rationally ignorant of most preprinted terms. Accordingly, it should not matter whether a preprinted term is clearly written and conspicuous. Unless the form taker is made aware of preprinted terms, such as through the negotiations or by a clear oral statement, even clearly written and conspicuous preprinted terms should be invalid if they would infringe on the reasonable expectations of a form taker who has not read the preprinted terms. Thus, under the "knockout rule," when a contract is formed under U.C.C. section 2-207(1) by an exchange of forms, and the preprinted terms of the forms differ, all conflicting preprinted terms, whether or not clear and conspicuous, drop out, and the contract consists only of the terms on which the forms agree-which invariably means only typed or handwritten terms-and terms implied by law. ${ }^{173}$

169. See, e.g., Weaver v. American Oil Co., 257 Ind. 458, 460, 276 N.E.2d 144, 146 (1971); Gerhardt v. Continental Ins. Cos., 48 N.J. 291, 296-98, 225 A.2d 328, 332-33 (1966).

170. That is, if the consumer pays $\$ Y$ for a contract, and the price for a contract that did not include the relevant term would have been the lower price $\$ X$, then the form giver has in effect "paid" the consumer $\$ Y-\$ X$ for accepting a contract with the relevant term.

171. 350 F.2d 445,449 (D.C. Cir. 1965).

172. 225 A.2d at 332.

173. See Daitom, Inc. v. Pennwalt Corp., 741 F.2d 1569, 1579 (10th Cir. 1984) (holding that conflicting terms in offer and acceptance canceled out under the knockout rule). 
In short, the rule governing the enforceability of preprinted terms in both the contract-formation and the enforceability stages should not turn on fairness, as in the doctrine of unfair surprise. Rather, the rule should turn strictly on the limits of cognition, as under U.C.C. section 2-207(1). This result is supported by the basic principles of interpretation. Under those principles, a contract between $A$ and $B$ is interpreted according to the meaning attached to it by $A$ even if $B$ attached a different meaning, if either (1) A did not know of any different meaning attached by B, and B knew the meaning attached by A; or (2) A had no reason to know of any different meaning attached by $B$, and $B$ had reason to know the meaning attached by A. ${ }^{174}$ Section 211 of the Restatement Second of Contracts ("Standardized Agreements") specifically applies these principles to form contracts. Section 211(1) provides:

[W] here a party to an agreement signs or otherwise manifests assent to a writing and has reason to believe that like writings are regularly used to embody terms of agreements of the same type, he adopts the writing as an integrated agreement with respect to the terms included in the writing. ${ }^{175}$

Section 211(3) then qualifies that rule: "Where the other party has reason to believe that the party manifesting such assent would not do so if he knew that the writing contained a particular term, the term is not part of the agreement."176 Comment $c$ and illustration 6 to section 211 make clear that the application of section 211(3) does not depend upon an independent showing of a lack of conspicuousness or clarity or other kinds of unfairness. ${ }^{177}$ Rather, it turns strictly on the limits of cognition.

Weaver $v$. American Oil Co. ${ }^{178}$ takes a similar position. This case involved a complex and legalistically phrased provision that effectively required the operator of an Amoco gas station to indemnify Amoco against liabilities for injuries caused by Amoco's own negligence. The court held that the provision was unenforceable, because "[ $t]$ he party seeking to enforce such a contract has the burden of showing that the provisions were explained to the other party and came to his knowledge and there was in fact $a$ real and voluntary meeting of the minds and not merely an objective meeting."179 As section 211 and Weaver show, the law is properly moving toward basing the enforceability of preprinted terms, as well as the role of such terms in contract formation, purely on the limits of cognition, rather than on unfairness.

174. Restatement (SeCOND) of Contracts § 201(2) (1979).

175. Id. $\$ 211(1)$.

176. $I d . \S 211(3)$.

177. Illustration 6 states:

A ships goods via $B$, a carrier. B carries an insurance policy with $C$, an insurance company, and with C's authority issues to A a certificate that A's shipment is insured under the policy. The policy contains a clause excluding coverage of trips on the Great Lakes unless approved by $\mathrm{D}$, an individual, but this clause is not referred to in the certificate or known to $\mathrm{A}$. It is not part of the contract between $A$ and $C$.

Id. cmt. $f$ illus. 6 .

178. 257 Ind. 458,276 N.E.2d 144 (1971).

179. 276 N.E.2d at 148; cf. N.Y. GeN. ObLIG. LAw § 5-702 (McKinney 1989) (requiring the use of plain language in consumer contracts). 


\section{Bargains To Waive Fiduciary Obligations}

If an actor has a significant degree of managerial or other control over assets that belong in whole or in part to others, the relationship between the actor and the others normally is deemed a fiduciary relationship and imposes upon the actor certain fiduciary obligations. Call the actor a manager, and those to whom the manager owes fiduciary obligations the beneficiaries. Paramount among the manager's fiduciary obligations is the duty of loyalty, which requires the manager to deal fairly when he deals with or in relation to the assets or uses his fiduciary position in his own self interest. These fairness obligations include the duties to make full disclosure, to deal on fair terms, to not use the assets without making fair compensation, and to not make a separate profit through use of his position. ${ }^{180}$

An important issue in the law governing fiduciary relationships is the extent to which fiduciary obligations should be treated as default rules, which can be waived by agreement of the beneficiaries, or as mandatory rules, which cannot be waived by agreement. ${ }^{181}$ Given the limits of cognition, the core duty-ofloyalty rules should not be subject to a general waiver.

To begin with, because of bounded rationality the beneficiaries could not possibly identify all the varying circumstances to which a general waiver of the duty of loyalty would apply. Furthermore, the beneficiaries would likely be unduly optimistic about the extent to which the manager would deal fairly despite the lack of fiduciary restraints. The availability and representativeness heuristics would enhance such undue optimism: Beneficiaries would tend to give undue weight to their good relationship with the manager at the time of contract formation, because that relationship is vivid, concrete, and instantiated, as compared with the possibility that the manager would exploit the bargain at some point in the future, which is abstract, general, and pallid, and would tend to overestimate the extent to which the present relationship with the manager is a reliable index of the future relationship. Similarly, faulty telescopic faculties would lead the beneficiaries to give undue weight to the present benefits of the relationship as compared to the future costs of the waiver. Finally, beneficiaries would tend to underestimate the risks that the waiver entailed. Thus, a general waiver of the duty of loyalty would inevitably permit unanticipated opportunistic behavior on the part of managers.

On the other hand, managers might not as easily exploit an agreement to govern a specific self-dealing issue. Informed consent to a specific conflict-ofinterest transaction, for example, may not suffer from defective cognition, because the consent would relate to a specific present event rather than to an unknowable future. An agreement that a specific type of business venture will not be deemed a corporate opportunity may also fall into this category.

180. See, e.g., Principles of Corporate Governance: Analysis and Recommendations $\S \S 5.02,5.04$ (1994).

181. See generally Symposium, Contractual Freedom in Corporate Law, 89 Colum. L. REv. 1395 (1989). 
The law concerning fiduciary obligations reflects these cognitional problems. The core duty-of-loyalty rules governing corporate fiduciaries cannot be waived, ${ }^{182}$ but courts may give effect to highly specific agreements that do not present the dangers of systematic unforeseeability and potential for exploitation. ${ }^{183}$ Similarly, a number of recent statutes permit a corporation's certificate of incorporation to limit or eliminate the personal liability of directors for simple duty of care violations, but most of these statutes explicitly exclude from their ambit violations of the duty of loyalty and the obtaining of improper benefits. ${ }^{184}$ More generally, section 5.09 of the American Law Institute's Principles of Corporate Governance: Analysis and Recommendations provides that courts should give effect to standards adopted by a corporation to govern conflict of interest transactions only if the standards meet certain requirements, including specificity:

If a director . . . or senior executive ... acts in reliance upon a standard of the corporation ... that authorizes a director or senior executive to either:

(a) Enter into a transaction with the corporation that is of a specified type...;

(b) Use corporate position or corporate property in a specified manner...; [or]

...

(d) Engage in competition of a specified type; and the standard was authorized in advance by disinterested directors ... or disinterested shareholders ... following disclosure concerning the effect of the standard and of the type of transaction or conduct intended to be covered by the standard, then the standard is to be deemed equivalent to an authorization of the action in advance by disinterested directors or shareholders . . . . 185

182. See, e.g., Pappas v. Moss, 393 F.2d 865, 867-68 (3d Cir. 1968) (stating that the burden is on interested directors to prove the fairness of a sale of stock to those directors, despite a provision in the certificate of incorporation that directors had the power to sell stock to themselves; "[W] think the burden was not shifted because of the Certificate provision in question. The very nature of the transaction here is such that it calls for pervasive scrutiny."); Abeles v. Adams Eng'g Co., 35 N.J. 411, 428-29, 173 A.2d 246, 255 (1961) (holding that the plaintiff had the burden of proving the faimess of an agreement between it and defendant corporation, with whom it shared a director, despite a provision in defendant's certificate of incorporation that no contract between that corporation and another corporation should be affected by the fact that the contracting parties had one or more common directors; the court noted "the soundness of the rule authorizing scrutiny regardless of the charter clause"); see also Labovitz v. Dolan, 189 Ill. App. 3d 403, 416, 545 N.E.2d 304, 313, 136 Ill. Dec. 780, 789 (1989) (stating that there is "no authority ... for the position that there can be an a priori waiver of fiduciary duties in a partnership-be it general or limited").

183. See Piccard v. Sperry Corp., 48 F. Supp. 465, 469 (S.D.N.Y. 1943), aff'd per curiam, 152 F.2d 462 (2d Cir.), cert. denied, 328 U.S. 845 (1946); Sterling v. Mayflower Hotel Corp., 33 Del. Ch. 293, 313-14, 93 A.2d 107, 118 (1952); Hackett v. Diversified Chem., Inc., 180 So. 2d 831, 834-35 (La. Ct. App. 1965); Everett v. Phillips, 288 N.Y. 227, 236-37, 43 N.E.2d 18, 20-22 (1942); Adams v. MidWest Chevrolet Corp., 198 Okla. 461, 473, 179 P.2d 147, 160 (1946).

184. See Principles of Corporate Governance: Analysis and Recommendations $\$ 7.17 \mathrm{re-}$ porter's note 4 (1994); see, e.g., DEL. CODE ANN. tit. 8, \& 102(b)(7) (1991) (authorizing provisions in certificates of incorporation that eliminate or limit directors' personal liability for monetary damages for breach of certain duties).

185. Principles of Corporate Governance: Analysis and Recommendations $\$ 5.09$ (1994). The comment adds:

Neither Part V [Duty of Fair Dealing] in general, nor $\$ 5.09$ in particular, permits the corporation's directors or shareholders to dispense generally with or generally modify the 
Partnership law is taking a similar tack. The Revised Uniform Partnership Act provides:

The partnership agreement may not...

(3) eliminate the duty of loyalty . . but:

(i) the partnership agreement may identify specific types or categories of activities that do not violate the duty of loyalty, if not manifestly unreasonable; or

(ii) all of the partners or a number of percentage specified in the partnership agreement may authorize or ratify, after full disclosure of all material facts, a specific act or transaction that otherwise would violate the duty of loyalty;

(4) unreasonably reduce the duty of care ... ;

(5) eliminate the obligation of good faith and fair dealing ..., but the partnership agreement may determine the standards by which the performance of the obligation is to be measured, if the standards are not manifestly unreasonable ....186

These and comparable restrictions on agreements to waive fiduciary duties reflect still another area of law in which legal rules that restrict the enforceability of contracts are best explained by the limits of cognition, although not explicitly based on those limits.

\section{E. Contracts To Govern the Ongoing Conduct of Thick Relationships}

Certain kinds of contracts govern relationships characterized by an involvement that is personally intensive, broad in scope, and potentially long-lasting. Examples include marriage, employment, partnership, and co-shareholdership in close corporations. I will call such relationships thick relationships.

The limits of cognition are especially troublesome in the context of contracts to govern thick relationships. The nature of thick relationships makes it virtually impossible to predict, at the time the contract is made, the contingencies that may affect the relationship's future course. Furthermore, at the time the contract is made, each party is likely to be unduly optimistic about the relationship's long-term prospects and the willingness of the other party to avoid opportunistic behavior or unfair manipulation of the relevant contractual

substantive and procedural rules ... that govern conduct of directors and senior executives and the judicial review of such conduct (as contrasted with the approval of a specific transaction or type of transaction)....

This limitation is based ... in part on the limits of consensual arrangements. ...

Section 5.09 reflects the view that a shareholder could not foresee the consequences of agreeing to waive every rule, because the varying circumstances to which such a waiver would be applicable could not be anticipated for at least some rules. For example, shareholders could not foresee the consequences of agreeing to waive the rule that self-dealing is subject to a faimess review, or the rule that the burden of proof in such a review is on the interested party in the absence of approval by disinterested directors, a disinterested superior, or disinterested Id. cmt. shareholders.

186. Revised Unif. Partnership Act § 103(b) (1994).

Similar restrictions apply in the law of trusts. See UNIF. Prob. CODE § 7-302 (1991) (describing a trustee's standard of care and performance). 
rules as the relationship unfolds. Finally, because of defects in capability the parties are likely to give undue weight to the state of their relationship as of the time the contract is made, which is vivid, concrete, and instantiated; to erroneously take the state of their relationship at that point as representative of the relationship's future; and to give too little thought to and put too little weight on the risk that the relationship will go bad.

Long duration accentuates all these problems. John Stuart Mill, who argued that "[l]aisser faire ... should be the general practice" and "that every departure from it, unless required by some great good, is a certain evil,"187 nevertheless concluded that an

exception to the doctrine that individuals are the best judges of their own interest, is when an individual attempts to decide irrevocably now what will be best for his interest at some future and distant time. The presumption in favor of individual judgment is only legitimate, where the judgment is grounded on actual, and especially on present, personal experience; not where it is formed antecedently to experience, and not suffered to be reversed even after experience has condemned it. When persons have bound themselves by a contract, not simply to do some one thing, but to continue doing something ... for a prolonged period, without any power of revoking the engagement ... [any] presumption which can be grounded on their having voluntarily entered into the contract . . . is commonly next to null. ${ }^{188}$

As in the types of contracts previously considered, the problem raised by contracts to govern thick relationships is not a problem of unconscionability. Usually, neither party to such a relationship will have exploited the other at the time the contract was made. Quite the contrary, both parties will have probably been subject to exactly the same cognitive limits. If, after the passage of time, both parties want to get out of or modify the relationship, they can simply agree to rescind or modify the contract. Difficult problems arise, however, if party A comes to benefit at the expense of party B due to A's ability to exploit contractual provisions that did not foreclose such exploitation because of the parties' limited cognition at the time of contracting. In such a case, A will object to a rescission or modification.

Although a body of literature on relational contracts advocates rules that would hold such relationships together, ${ }^{189}$ this attempt is both quixotic and misguided. The law is equipped to make rules that will prevent one party from opportunistically using an insubstantial breach by the other party as an excuse for breaking a deal, but it is not equipped to make rules that will hold a relationship together. Nor should the law try to do so, because if it does, a party

187. John Stuart Mitl, Principles of Political Economy 950 (WJ. Ashley ed., 1961) (1848).

188. Id. at 959-60.

189. See, e.g., Robert A. Hillman, Contract Excuse and Bankruptcy Discharge, 43 STAN. L. Rev. 99, 131-33 (1990); Robert A. Hillman, Court Adjustment of Long-Term Contracts: An Analysis Under Modern Contract Law, 1987 DukE L.J. 1; Ian R. Macneil, Economic Analysis of Contractual Relations: Its Shortfalls and the Need for a "Rich Classificatory Apparatus," 75 Nw. U. L. REv. 1018, 1032-34 (1981); Richard E. Speidel, Court-Imposed Adjustments Under Long-Term Supply Contracts, 76 Nw. U. L. REv. 369 (1981); Richard E. Speidel, Excusable Nonperformance in Sales Contracts: Some Thoughts About Risk Management, 32 S.C. L. Rev. 241, 271-80 (1980). 
considering exploitation will know that the other will not be able to respond by terminating the relationship. The solution to the problems presented by contracts to govern thick relationships is not to try to enforce the contract and thereby keep the relationship together, but to allow either party the right to easy exit on fair terms, even if easy exit is not written into the contract.

The law already takes a number of half and even full steps toward this end. For example, employment contracts that do not state a duration are interpreted to be at will, rather than for a reasonable time, ${ }^{190}$ and employment contracts cannot be specifically enforced whether or not they state a duration. ${ }^{191}$ Contracts to govern the ongoing conduct of a marriage are unenforceable, ${ }^{192}$ and under modern no-fault divorce statutes, marriage itself is freely dissoluble.

Similarly, a partnership can be dissolved at any time by any partner. ${ }^{193}$ Hetherington and Dooley have advocated an analogous rule for close corporations, on essentially cognitional grounds:

The emphasis on contractual arrangements [to address the problems of minority shareholders in close corporations] reveals a fundamental misunderstanding of the nature of close corporations. Whether the parties adopt special contractual arrangements is much less important than their ability to sustain a close, harmonious relationship over time. The continuance of such a relationship is crucial because it reflects what is perhaps the fundamental assumption made by those who decide to invest in a close corporation: they expect that during the life of the firm the shareholders will be in substantial agreement as to its operation.

Time and human nature may cause a divergence of interests and a breakdown in consensus, however.

$\cdots$

... [T] he problem of exploitation is uniquely related to illiquidity and, for that reason, it is resistant to solution by ex ante contractual arrangements .... Accordingly ... [the law should require] the majority to repurchase the minority's interest at the request of the latter and subject to appropriate safeguards. ${ }^{194}$

Although corporation law has yet to move as far as Hetherington and Dooley advocate, the general trend has been toward allowing the courts to grant petitions for dissolution on the ground that the complaining shareholder's reasonable expectations were being defeated, and converting the actual relief granted to a mandatory buyout of the complainant's interest at fair value. ${ }^{195}$

190. See Clyde W. Summers, Individual Protection Against Unjust Dismissal: Time for a Statute,

62 VA. L. REV. 481, 484-85 (1976).

191. See Restatement (Second) of Contracts $\$ 167(1)$ (1979).

192. See Miller v. Miller, 78 Iowa 177, 35 N.W. 464, 42 N.W. 641 (1889); Balfour v. Balfour, [1919] 2 K.B. 571 (1919).

193. See UNIF. PARTNERSHIP Act § 31 (1969).

194. J.A.C. Hetherington \& Michael P. Dooley, Illiquidity and Exploitation: A Proposed Statutory Solution to the Remaining Close Corporation Problem, 63 VA. L. REv, 1, 2, 3, 6 (1977).

195. See, e.g., In re Judicial Dissolution of Kemp \& Beatley, Inc., 64 N.Y.2d 63, 473 N.E.2d 1173, 484 N.Y.S. 799 (1984). 
Given the limits of cognition, the tendency of the law to allow easy exit on fair terms from thick relationships is desirable and should be extended.

\section{F. Prenuptial Agreements}

Prospective spouses may make contracts to govern their property rights during marriage or upon death. Both statutory and common law have long recognized the enforceability of such contracts. ${ }^{196}$ Prospective spouses may also make contracts that specify their property and support rights in the event of divorce. Until the 1970 s, courts generally held such contracts to violate public policy. 197 Today, however, courts do not withhold enforcement of such contracts, which I will call prenuptial agreements.

The limits of cognition have an obvious bearing on the enforceability of prenuptial agreements. To begin with, individuals who plan to marry are often likely to be unduly optimistic about the fate of their marriage. ${ }^{198}$ Two people in love are likely to heavily discount the possibility of divorce, because they will overemphasize the concrete evidence of their currently thriving relationship and underemphasize abstract divorce statistics; and because divorce is a risk that, like other risks, people systematically underestimate. ${ }^{199}$ As a result, prospective spouses are likely to heavily discount the probability that their prenuptial agreement will come into play.

Bounded rationality also poses a problem in this context. Because of the exceptionally indefinite nature of marriage, it is almost impossible to predict the impact that a prenuptial agreement will have if it does come into play. Personal income may increase or decrease; job skills may be acquired or lost; family obligations may vary in regard to both the other spouse and children; personal expectations may change. Change in the course of marriage is foreseeable, but the specifics of the change are not. The limits of cognition therefore provide a strong justification for a second-look approach to prenuptial agreements.

Although courts now treat prenuptial agreements as valid, they disagree over whether and to what extent a second-look approach to enforcement is permissible. The Pennsylvania Supreme Court, for example, refused to take a second look at such an agreement in Simeone v. Simeone. ${ }^{200}$ Catherine, an unemployed nurse, married Frederick, a neurosurgeon who was earning $\$ 90,000$ per year and had assets of almost $\$ 300,000$. On the eve of the wedding, and without consulting a lawyer, Catherine signed a prenuptial agreement that limited her potential support payments to $\$ 200$ a week, with a maximum total payment of $\$ 25,000$. The couple divorced after seven years of marriage.

196. See MASs. GEN. LAws ANN. ch. 209, § 25 historical notes (West 1992); Freeland v. Freeland, 128 Mass. 509 (1880); Pickett v. Chilton, 19 Va. (5 Munf.) 467 (1817).

197. See Posner v. Posner, 233 So. $2 d$ 381, 384 (Fla. 1970) (tracing the evolution of the courts' views).

198. See text accompanying notes $32-36$ supra.

199. See text accompanying note 33 supra.

200. 525 Pa. 392, 581 A.2d 162 (1990). 
After Frederick had paid Catherine $\$ 25,000$, she sought alimony. ${ }^{201}$ The court held that prenuptial agreements should be evaluated under exactly the same criteria applicable to other contracts. "Certainly," the court said,

the possibilities of illness, birth of children, reliance upon a spouse, career change, financial gain or loss, and numerous other events that can occur in the course of a marriage cannot be regarded as unforeseeable. If parties choose not to address such matters in their prenuptial agreements, they must be regarded as having contracted to bear the risk of events that alter the value of their bargains. ${ }^{202}$

Similarly, in Chiles v. Chiles, ${ }^{203}$ a Texas appellate court, in reversing the trial court's decision that a prenuptial agreement was unenforceable on unfairness grounds, held that it is immaterial whether such an agreement is fair or unfair. ${ }^{204}$

Courts that do take a second-look approach use various standards of review. Many employ a variant of the standard of the Uniform Premarital Agreement Act, ${ }^{205}$ adopted by a minority of state legislatures, ${ }^{206}$ and uphold the agreement unless enforcement would cause one party to become a burden on society. ${ }^{207}$ For example, in Bassler v. Bassler ${ }^{208}$ Linda and George entered into a prenuptial agreement in which Linda waived all present and future rights in any property owned or ever acquired by George. ${ }^{209}$ After the couple divorced, Linda required public assistance. She then sued for her interest in the marital estate, and George raised the prenuptial agreement as a defense. ${ }^{210}$ The Vermont

201. 581 A.2d at $163-64$.

202. Id. at 166.

203. 779 S.W.2d 127 (Tex. Ct. App. 1989).

204. Id. at 129; see also VA. CODE ANN. \$ 20-151(A) (Michie 1990) (premarital contracts are valid if fair and equitable when formed); Herget v. Herget, 77 Md. App. 268, 274, 276, 550 A.2d 382, 385,386 (1988) (holding that courts should not consider events after contract formation in judging the faimess of a prenuptial agreement), rev'd on other grounds, 319 Md. 466, 573 A.2d 798 (1990).

205. Unif. Premarital Agreement Act §§ 1-13 (1987).

206. 9B U.L.A. 46 (Supp. 1994).

207. See, e.g., Williams v. Williams, 166 Ariz. 260, 263, 801 P.2d 495, 498 (Ct. App. 1990) (" $[R]$ esults must not be made unconscionable ... such as when enforcement of the spousal maintenance waiver provision would render one spouse without a means of reasonable support or a public charge."); Lewis v. Lewis, 69 Haw. 497, 503, 748 P.2d 1362, 1367 (1988) (no enforcement of agreements which result in hardship which would "shock the conscience"); Osborne v. Osborne, 384 Mass. 591, 599, 428 N.E.2d 810,816 (1981) (holding that an agreement will be modified if a spouse would otherwise become a "public charge"); Unander v. Unander, 265 Or. 102, 107506 P.2d 719, 721 (1973) (holding that a prenuptial agreement is valid unless a spouse has "no other reasonable source of support").

The relevant text of UPAA $\$ 6$ reads:

If a provision of a premarital agreement modifies or eliminates spousal support and that modification or elimination causes one party to the agreement to be eligible for support under a program of public assistance at the time of separation or marital dissolution, a court, notwithstanding the terms of the agreement, may require the other party to provide support to the extent necessary to avoid that eligibility.

Unif. Premarital Agreement ACt $\S 6$ (1987). Note that $\S 6$ merely permits a court to order support to the extent necessary to avoid eligibility for welfare, but such eligibility does not make the underlying agreement unenforceable. In contrast, under the common law analog such eligibility may invalidate the entire agreement.

208. 156 Vt. 353, 593 A.2d 82 (1991).

209. 593 A.2d at 84 .

210. Id. at $84-85$. 
Supreme Court refused to enforce the agreement, on the ground that a prenuptial agreement that leaves one spouse a public charge at the time of divorce is unenforceable. ${ }^{211}$

A burden-on-society standard conforms in many respects to orthodox contract principles: It is minimally intrusive and will render an agreement unenforceable only under extreme circumstances. This test, however, does not fully reflect the special application of the limits of cognition to prenuptial agreements. Other authorities therefore take a more full-blooded second-look approach. ${ }^{212}$ For example, in Osborne v. Osborne ${ }^{213}$ David, a medical student, married Barbara, a fellow medical student and heiress to a $\$ 17$ million family fortune. Prior to the ceremony, the couple signed mutual agreements waiving any right to each other's property and any right to alimony. In the course of divorce proceedings, David sought both alimony and an equitable division of property. ${ }^{214}$ The Massachusetts Supreme Court held that a prenuptial agreement is enforceable only if it is fair and reasonable at the time of divorce.215 On that basis, the court held against David, who was a practicing doctor with a respectable salary. ${ }^{216}$ In Warren $v$. Warren, ${ }^{217}$ an agreement between Marcia and Marvin to waive support and property rights did not survive a second look by the Illinois Court of Appeals. At the time of the agreement, Marcia had a net worth of $\$ 70,000$ and Marvin had assets of roughly $\$ 7$ million. ${ }^{218}$ Upon divorce, the court held that the prenuptial agreement was unfair and therefore unenforceable, despite the fact that Marcia had sufficient assets to support herself for a time. ${ }^{219}$ In determining unfairness, the court noted that "for several years Marcia and Marvin lived a lifestyle far more extravagant than Marcia could hope to afford on her own."220

Courts often justify a full-blooded second-look approach to prenuptial agreements with the rhetoric of unconscionability. ${ }^{221}$ Unconscionability, however, classically refers to a showing that one party unfairly exploited the other

211. Id. at 87.

212. See, e.g., N.Y. Dom. Rec. LAw § 236(B)(3) (McKinney 1986); Newman v. Newman, 653 P.2d 728, 735 (Colo. 1982); Posner v. Posner, 233 So. 2d 381 (Fla. 1970); Scherer v. Scherer, 249 Ga. 635, 641, 292 S.E.2d 662, 666 (1982); In re Marriage of Burgess, 138 Ill. App. 3d 13, 15, 485 N.E.2d 504, 505 (1985); Osborne v. Osborne, 384 Mass. 591, 599, 428 N.E.2d 810, 816 (1981); McKee-Johnson y. Johnson, 444 N.W.2d 259, 261 (Minn. 1989); MacFarlane v. Rich, 132 N.H. 608, 617, 567 A.2d 585, 591 (1989); Marschall v. Marschall, 195 N.J. Super. 16, 28 n.3, 477 A.2d 833, 839 n.3 (1984); Gross v. Gross, 11 Ohio St. 3d 99, 109, 464 N.E.2d 500, 510 (1984), cert. denied, 476 U.S. 1117 (1986); Bassler v. Bassler, 156 Vt. 353, 361, 593 A.2d 82, 87 (1991); Gant v. Gant, 174 W. Va. 740, 747-48, 329 S.E.2d 106, 115 (1985); Button v. Button, 131 Wis. 2d 84, 98-99, 388 N.W.2d 546, 552 (1986).

213. 381 Mass. 591,428 N.E.2d 810 (1981).

214. 428 N.E. $2 \mathrm{~d}$ at 813.

215. Id. at 816 .

216. Id. at 814 .

217. 169 Ill. App. 3d 226, 523 N.E.2d 680 (1988).

218. 523 N.E.2d at 681 .

219. Id. at 684; see id. at 683 ("Although Marcia's assets are modest in comparison to Marvin's, they are sufficient to keep her from sinking into an imminent state of penury.").

220. Id. at 683.

221. See, e.g., Newman v. Newman, 653 P.2d 778, 734-35 (Colo. 1982); Lewis v. Lewis, 69 Haw. 497, 501-03, 748 P.2d 1362, 1366-67 (1988); Gross v. Gross, 11 Ohio St. 3d 99, 109, 464 N.E.2d 500, 510 (1984), cert. denied, 476 U.S. 1117 (1986). 
at the time the contract was made, or that the contract was unfairly one-sided at that time. ${ }^{222}$ The second-look approach to prenuptial agreements does not depend on such a showing. The New Jersey statute, for example, provides that a large disparity between the standard of living before marriage and the result under the agreement is "unconscionable." 223 Similarly, in Lewis v. Lewis the Hawaii Supreme Court said that "[a]s applied to premarital agreements, onesidedness would mean that the agreement leaves a post-divorce economic situation that is unjustly disproportionate."224 This willingness to refuse to enforce prenuptial agreements without a showing of unfair exploitation or one-sidedness at the time of contract formation suggests that unconscionability does not really drive these cases. Unconscionability is a fairness doctrine, and if a contract is fair when made, enforcement cannot be unfair. Rather, what drives these cases is the limits of cognition, because, unlike unconscionability, those limits justify a refusal to apply the bargain principle even if the contract was fair when made.

Thus, in Gant v. Gant ${ }^{225}$ the West Virginia Supreme Court properly concluded that "when courts talk about 'fairness' [of prenuptial agreements] they are usually not talking about an entirely subjective, open-ended concept. . . . Rather, what [these] courts are really concerned about is 'foreseeability.' "226 The court then inquired into whether the "circumstances at the time the marriage ends are roughly what the parties foresaw at the time they entered into the premarital agreement."227

Similarly, in Gross v. Gross ${ }^{228}$ the Ohio Supreme Court held that alimony provisions of prenuptial agreements, even if valid and enforceable when formed, will not be strictly enforced when they have become "unreasonable or unconscionable as to [their] application to the spouse upon divorce."229 Examples were:

an extreme health problem requiring considerable care and expense; change in employability of the spouse; additional burdens placed upon a spouse by way of responsibility to children of the parties; marked changes in the cost of providing the necessary maintenance of the spouse; and changed circumstances of the standards of living occasioned by the marriage, where a return to the prior living standard would work a hardship upon a spouse. ${ }^{230}$

222. See note 118 supra and accompanying text.

223. N.J. Rev. Stat. ANn. § 37:2-32(c)(2), -38(b) (West Supp. 1994).

224. Lewis, 748 P.2d at 1366; see also Newman, 653 P.2d at 734 (holding that maintenance terms of prenuptial agreement could be voidable for unconscionability "even though [the] agreement is entered into in good faith, with full disclosure and without any element of fraud or overreaching"); Gross, 464 N.E.2d at 510 (holding that maintenance terms in a prenuptial agreement were unconscionable because of the disparity between the spouse's married lifestyle and the lifestyle that would result from enforcement of the agreement).

225. 174 W. Va. 740, 329 S.E.2d 106 (1985).

226. 329 S.E.2d at 114-15.

227. Id. at 116 .

228. 11 Ohio St. 3d 99, 464 N.E.2d 500 (1984), cert. denied, 476 U.S. 1117 (1986).

229. 464 N.E.2d at 509.

230. Id. n.11. 
The court then found that although the agreement was fair, because it was entered into in good faith, without overreaching, and with full disclosure, it was unenforceable in light of changed circumstances:

... [T]he facts would tend to show that, although a comparatively wealthy man at the time of the execution of the antenuptial agreement, Mr. Gross became a man of considerably greater means during the years of his second marriage. Not only did his stock holdings and the value thereof increase markedly, but his net income also substantially increased. The wife's standard of living has changed quite dramatically from the time of the execution of the agreement until the time of the divorce. To require the wife to return from this opulent standard of living to that which would be required within the limitations of the property and sustenance provisions of this agreement, could well occasion a hardship or be significantly difficult for the former wife. ${ }^{231}$

The Gant and Gross courts got the question just right. Ultimately, in reviewing a prenuptial agreement for a marriage whose circumstances have significantly changed, the court must decide whether, in light of all relevant factors, the parties were likely to have had a mature understanding that the agreement would apply even in the kind of marriage scenario that actually occurred.

\section{CONCLUSION}

The law has always recognized the limits of cognition in a tacit manner. For example, mandatory social security rests on the tacit assumption that individuals will not appropriately allocate their income between present and future consumption. Similarly, many safety rules, such as those that prohibit the marketing of pharmaceuticals not yet proven effective, rest on the tacit assumption that consumers are incapable of adequately understanding certain kinds of information. It is only within the very recent past, however, that the empirical evidence concerning the limits of cognition and the theoretical framework for that evidence have established a formal scientific foundation for these assumptions.

In light of how recently this scientific foundation has been built, it is not surprising that courts for the most part have not justified the principles governing the limits of contract on the basis of the limits of cognition. Nevertheless, many of these principles, such as those discussed in this article, undoubtedly arose and persisted on the basis of a tacit understanding of those limits. Now that the scientific foundation of those limits has been established, it is time to recognize that explanation explicitly, partly to make the principles more transparent to testing, and partly because explicit recognition of the role of the limits of cognition helps to show how we should shape existing principles and what new principles we should develop.

In this article, I have examined only a few principles that limit contract, but an analysis based on the limits of cognition can easily be extended to other contract principles as well. Those limits can explain, for example, the U.C.C. 
rule that where circumstances cause an exclusive or limited contractual remedy "to fail of its essential purpose," the remedy will not be given effect:232 Contractual limitations of remedies are nonperformance terms, and are therefore subject to the cognitional problems that.beset other such terms, like liquidated damages provisions and express conditions. Similarly, the limits of cognition can explain, at least in part, why gifts are irrevocable while promises to make gifts are unenforceable: The actual transmission of a gift powerfully focuses the donor's cognition on the consequences of her act. The limits of cognition also underpin the doctrines of mutual mistake and changed circumstances, in that both of these doctrines are in significant part based on bounded rationality. 233

Of course, the limits of cognition are not a universal explanation of either contract law or the limits of contract. Other teachings of experience, as well as concepts of efficiency and morality, also play leading roles. ${ }^{234}$ Even those other elements, however, can be given appropriate weight only when we know the psychological framework within which actors operate when making choices. 
